Article

\title{
Decentralized Renewable Hybrid Mini-Grids for Rural Communities: Culmination of the IREP Framework and Scale up to Urban Communities
}

\author{
Blessing Ugwoke ${ }^{1,2, *(\mathbb{D}}$, Adedoyin Adeleke ${ }^{3}$, Stefano P. Corgnati ${ }^{1}$, Joshua M. Pearce ${ }^{2,4}(\mathbb{D}$ and \\ Pierluigi Leone ${ }^{1}$ \\ 1 Energy Center Lab, Department of Energy Politecnico di Torino, 10138 Torino, Italy; \\ stefano.corgnati@polito.it (S.P.C.); pierluigi.leone@polito.it (P.L.) \\ 2 Department of Materials Science \& Engineering and Department of Electrical \& Computer Engineering, \\ Michigan Technological University, Houghton, MI 49931, USA; pearce@mtu.edu \\ 3 Department of Energy, Politecnico di Milano, 20156 Milano, Italy; adedoyin.adeleke@polimi.it \\ 4 Department of Electronics and Nanoengineering, School of Electrical Engineering, Aalto University, \\ 02150 Espoo, Finland \\ * Correspondence: blessing.ugwoke@polito.it
}

Received: 17 July 2020; Accepted: 7 September 2020; Published: 9 September 2020

\begin{abstract}
The Integrated Rural Energy Planning (IREP) framework offers a unified road map for locating, planning and operating decentralized renewable hybrid off-grid energy systems for localized (rural) applications in low-income countries. This paper presents the culmination of the IREP framework and aims to illustrate the final step of the IREP framework for two communities in Nigeria. It is focused on two aspects. Firstly, the techno-economic modeling (investment and operation optimization) of a hybrid mini-grid system using HOMER Pro, a techno-economic evaluation tool; and evaluating the benefits of demand side management (DSM) based on energy efficiency on the overall system economics using a scenario-based approach. Secondly, the conceptualization of a sustainable business model using the business model canvas scheme to deliver measurable socio-economic impacts in these communities. The results provide valuable insights into rural electrification via renewable hybrid mini-grids powered primarily with solar photovoltaic technology. Transcending mere electricity access, electricity is provided for productive uses (considering disaggregated end-uses) by harnessing other dispatchable renewable energy resources such as waste biomass. Given high share of rural population in developing countries, these insights are applicable in these regions and further the realization of the United Nations' goal of sustainable energy (SDG7) and sustainable cities and communities (SDG11).
\end{abstract}

Keywords: hybrid mini-grids; rural community; Nigeria; business model; sustainable development; renewable energy

\section{Introduction}

The incidence of energy poverty, energy insecurity and low electricity access has persisted around the globe, especially in sub-Saharan Africa, where high tariffs and unreliable and unavailable energy access are a stark reality [1,2]. The United Nations' goal of affordable and clean energy (SDG7) embodies a magnificent vision [3], but its realization has not progressed extensively particularly at addressing the socio-economic dichotomy prevalent in sub-Saharan Africa [4-6] and the socio-cultural intricacies involved $[7,8]$. Previous studies highlight the need to harmonize the lessons learned from experience into a standardized and holistic integrated framework for improving localized energy access in sub-Saharan Africa $[9,10]$. In order to fill this gap, the Integrated Rural Energy Planning framework 
(IREP) was developed to offer a unified road map for locating, planning and operating decentralized renewable hybrid off-grid energy systems for localized (rural) applications in low-income countries [11]. IREP stems from the consensus formed, that decentralized renewable energy may be most appropriate for electrifying these regions to enable them to leapfrog the development of conventional centralized grids [1,12-15]. IREP provides a systematic and decentralized planning approach that accentuates the development of indigenous renewable energy resources to invigorate sustainable development at localized scales [12]. Overall, the IREP framework entails a multi-faceted scheme that considers crucial factors to spur sustainable investments, drive down operating costs and consequently raise the affordability of electricity service for the different customer segments within the developing world context [16]. Nigeria was selected as case study for the framework due to the combination of its precarious energy access situation [9] and the relevance of its economic characteristics in the African region and the globe $[17,18]$. Nigeria presents a relevant case study for the developing world especially countries in sub-Saharan Africa. The IREP framework, which buttresses features of the Integrated Rural Planning (IRP) approach [19,20] and the Integrated Energy Planning (IEP) concept [21,22], encompasses three methodical action steps [11]. The first step, already accomplished for Nigeria, entails the site identification and selection [11] performing robust energy demand estimation with the reference building approach [23]. The second step, which encompasses forecasting energy supply and demand over a long period, was demonstrated considering community scale case studies in Nigeria [24]. The third and final step, which is the basis for this study, provides detailed technical modeling for optimal configurations of off-grid energy systems at local scales as well as plausible business models for sustainable deployment and operation of these systems.

Therefore, the study being the culmination of the IREP framework is focused on detailed energy system planning, design and configuration for decentralized renewable hybrid mini-grids. The aim is to illustrate the final step of the IREP framework for two communities in Nigeria. It is focused on two aspects. Firstly, the techno-economic modeling (investment and operation optimization) of a hybrid mini-grid system using HOMER Pro, version 3.13.3 (HOMER Energy, Boulder, CO, USA) and evaluating the benefits of demand side management (DSM) based on energy efficiency on the overall system economics. The effects of these energy conservation options are analyzed using a scenario-based approach. Secondly, the conceptualization of a sustainable business model using the business model canvas scheme to deliver measurable socio-economic impacts in these communities. The results of applying this approach to two communities in Nigeria will be discussed in the context of the generalized IREP framework for the region and the rest of the rural developing world.

\section{Background on Renewable Hybrid Mini-Grids}

A 'mini-grid' has been referred to as a system of local electricity supply often renewable energy (RE) based (with a capacity $\geq 10 \mathrm{~kW}$ ), supplying electricity to a target set of consumers (residents for household usage, commercial, productive, industrial and institutional setups, etc.) through a local distribution network operating either in an isolated mode or in a grid-interactive mode $[25,26]$. Renewable hybrid mini-grids (RHMGs) refer to mini-grids that incorporate two or more electricity generation options encompassing renewable energy (RE) resources coupled to other RE and/or fossil fuel units [27]. They often utilize a significant share of RE resources and may operate either in an isolated mode or in a grid-interactive mode [26]. A typical RHMG may consist of a generating capacity incorporating two or more RE-based generators, a local distribution network, a storage unit (battery banks, pumped hydro storage, flywheel, etc.) and balance of system (BoS) hardware (tracker, inverter, controller, mechanical hardware, etc.) [28]. RHMGs have numerous advantages over single source-based decentralized energy systems. They are more efficient and reliable, with reduced storage capacity needs $[26,27,29]$, and provides the most cost-effective alternative for rural electrification [30]. While RHMGs are the most cost-effective, they are complicated systems that demand detailed energy system planning, design and sizing. This is normally further complicated by a process that involves preliminary modeling, business model conceptualization, resource planning, and project 
engineering and development [26]. Optimization requires tools for execution and to inform the technical and economic evaluation of these systems. Several free and commercial tools have been developed to do this and can be broadly classified into three groups: (i) higher-level techno-economic evaluation tools, (ii) technical evaluation tools and (iii) broader energy planning tools. Comprehensive discussions, descriptive and comparative analysis have been carried out on these tools and their features $[27,31,32]$. The higher-level techno-economic evaluation tools have been most researched across different studies [27,31,32]. Among the tools, HOMER is found to be the most widely used tool for hybrid system analysis by several researchers worldwide $[27,33,34]$. Some of these studies are discussed by means of extensive topical case study reviews across national [9], international [33] and regional [34] geographic scopes. Across the reviews, solar resource was the most investigated RE resource especially in collaboration with other RE technology applications and resources, namely, wind and hydro. The solar photovoltaic (PV) is a well-established sustainable energy technology [35], whose diffusion has recorded remarkable growth [36-39] with a drastic and progressive [40] reduction in price. Given the intermittency and non-dispatchability characteristics with some of these RE resources (solar and wind), there is the need to integrate either storage or some other dispatchable resources such as biomass that would compensate for the inadequacies attributed to solar and wind [41].

Globally, the potential of biomass for decentralized power generation remains largely unexploited [42]. The Nigerian case typifies this. The country produces 781,000 tons of animal waste/day, which are largely untapped for energy generation, while its daily production of 120,000 tons of fuelwood are ineffectively and traditionally used for cooking [9]. Overall, Nigeria has an untapped 91.4 million tons per year of agricultural residues that could be used for bioenergy [9]. These resources could be harnessed for clean energy production to meet the base load to serve the energy needs at community levels without the need for short-term storage [26]. However, the viability of such decentralized energy systems is location dependent and contingent on the seasonality inherent with the supply of these resources. Also, other interventions such as energy conservation through demand side management (DSM) that can be harnessed to further sustainable energy access have remained largely unexplored [43].

\section{Topical Case Studies on Optimal System Design, Sizing and Configuration of RHMGs}

Several studies conducted on optimal system design, sizing and configuration of RHMGs have been carried out across different topics encompassing technical and economic evaluation, feasibility analysis, DSM and business models. These are expatiated below, largely focusing on studies that incorporated biomass resources in their analyses.

Studies have been carried out to elucidate the technical and economic evaluation of RHMGs, in which performance evaluation of decided systems are implemented in order to obtain insights on detailed behavior of the system. These studies provide detailed descriptions of the technical design and economic evaluation of the proposed energy systems. Islam et al. [44] investigated the adoption of a solar and rice- husk-based biomass gasifier system for electrifying a northern rural off-grid region in Bangladesh. Yimen et al. [45] performed the techno-economic analysis of a solar, wind, biogas and pumped-hydro storage based system for Djoundé, a small village in northern Cameroon. A dedicated system design, implementation and validation was carried out for a microgrid composed of solar, wind, biomass and vanadium redox flow battery (VRFB) storage at India Institute of Engineering Science and Technology campus [46]. Based on a hybrid standalone system in Bihar, India, Mazzola et al. [47] investigated the potential of wood biomass for rural electrification considering a down-draft gasifier coupled with an internal combustion engine (ICE) and a boiler coupled with an Organic Rankine Cycle (ORC) system. Using Kallar Kahar in Pakistan as a case study, a grid-tied wind, PV and biomass microgrid system was studied for the purpose of rural electrification [48]. These studies have shown that integrating RE sources technologies has the economic benefits of reducing the overall system cost and the levelized cost of electricity (LCOE). 
Studies bordering on feasibility analysis have performed design optimization considering different energy system configurations, scenarios and technologies to proffer optimal design solutions, and insights to support decision making on required capital investments. They included techno-economic assessments and sustainability analyses for combination and sizing of system components, energy resources and energy demand assessments, costs assessments, social elements and environmental parameters. Barakat et al. [49] performed a feasibility study of a grid connected solar and biomass system for rural electrification of Monshaet Taher village, Egypt. This study provided inputs for Eteiba et al. [50], who carried out design optimization for an off-grid hybrid solar and biomass system considering different battery technologies. Considering the efficacy of local agricultural residues for decentralized electrification, the feasibility of mini-grid electricity service was investigated for five Ghanaian communities based on agricultural waste gasification [50]. An integrated system consisting of photovoltaics (PV), combined heat and power (CHP) biogas generator, vanadium redox batteries, water electrolyzer and hydrogen storage with fuel cell was modelled for a village in West Bengal, India, to determine the optimal system configuration for rural electrification [51]. Rajbongshi et al. [52] performed a feasibility study of a PV, biomass gasifier and diesel system operating in autonomous and grid connected mode for Jhawani village, India. Considering Garissa district in Kenya, a feasibility study was performed for a decentralized PV wind battery system with a biogas engine as the system's backup [53]. Following Cameroon's National Energy Action Plan, Nfah and Ngundam [54] performed feasibility studies of RE systems incorporating hydro, solar and biogas generators for electrifying remote villages.

For conservation to reduce the size of the hybrid systems, DSM implementation has been broadly grouped into demand response (DR) and energy efficiency (EE) strategies [55,56]. DSM can also play an important role in integrating RE into localized energy systems [31]. Therefore, some studies have incorporated DSM functionality by means of DR as planned interventions to minimize overall system costs and capital investments. Montuori et al. [43] utilized DR functionality to compensate for supply variability in a biomass integrated energy system. A Model Predictive Control (MPC) strategy was adopted in collaboration with a DR program to model the optimal dispatch mode for grid-tied solar, wind, biomass and hydrogen renewable energy systems [41]. Mehra et al. [57] evaluated the performance and cost curtailment potential of on-site DSM capabilities for battery integrated solar micro grids.

Business models provide the basis for the long-term sustainability of RHMGs in terms of their financing, implementation, operation and maintenance options for different value chains [58] and cut across different value streams [59]. Several classification schemes have been proposed for business models based on existing literature [29,30,60-62] and are summarized in Figure 1. These encompass a variety of structuring options. However, business models must be well-designed to consider local conditions, and inherent limitations, in addition to political, financial, institutional, social, technological and environmental peculiarities. Islam et al. [44] proposed a business model for operating a solar and rice husk-based biomass gasifier system for a rural region in Bangladesh. Emerging disruptive business models such as cooling as a service (CaaS), targeting low-income countries are providing for productive use of energy at affordable prices [63] in the developing world. 


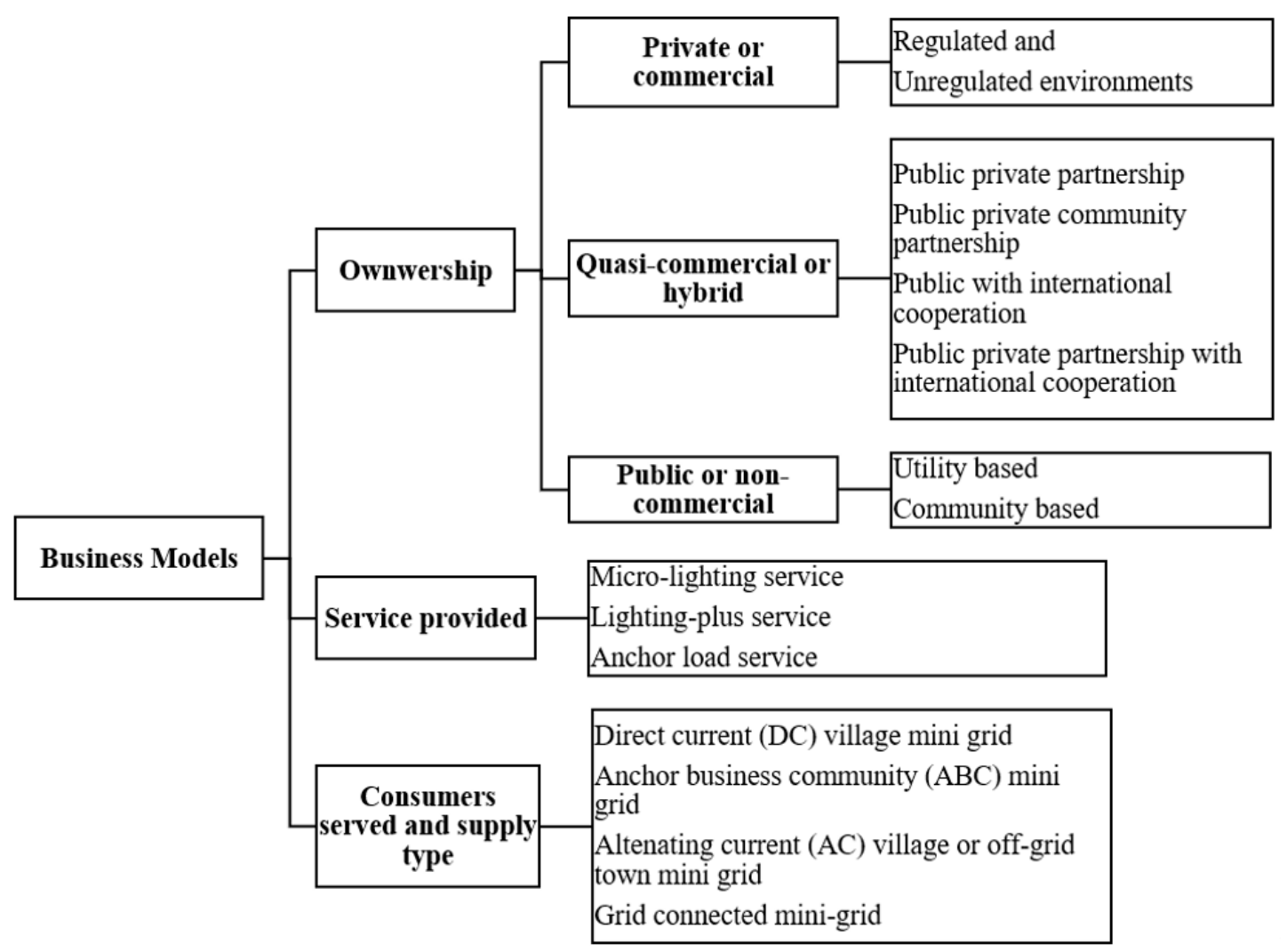

Figure 1. Classification of mini-grid business models (source: from the authors).

\section{Methods and Materials}

\subsection{Detailed Energy System Planning, Design and Configuration}

The overall method entailed design, sizing, technical and financial evaluation of RHMGs for decentralized generation for rural electrification. This encompassed systematic steps including the tools and analysis as shown in Figure 2. HOMER Pro version 3.13.3, a techno-economic evaluation tool, was utilized to implement the simulation, optimization, scenario analysis and sensitivity analysis steps [64]. HOMER Pro models the actual physical (technical), economic and environmental contexts with which to obtain the least cost combination of components that meet electrical loads considering a given system configuration. The optimization step considers several system configurations to identify the optimal configuration based on the lowest life-cycle cost from a list of feasible system configurations. In the sensitivity analysis step, multiple optimizations are performed considering a range of input values to effects of uncertainty or changes in the model inputs on overall project economics and results obtained [65]. With the scenario analysis, there is then the possibility to consider the effects of energy conservation interventions such as DSM. These measures are evaluated to determine their efficacy to deliver the benefits of cost minimization and reduced environmental impacts [66].

The business model conceptualization step entails the development of business models for sustainable deployment of RHMGs while bolstering a local supply chain to invigorate the local economy. This was done with Business Model Canvas (BMC) tool [67], which was incorporated for the business model conceptualization process. The BMC offers a conceptualization tool and contemporary framework used to design and illustrate business models based on the four basic constructs of the business model theory, namely, product, customer interface, infrastructure management and financial aspects [68]. 


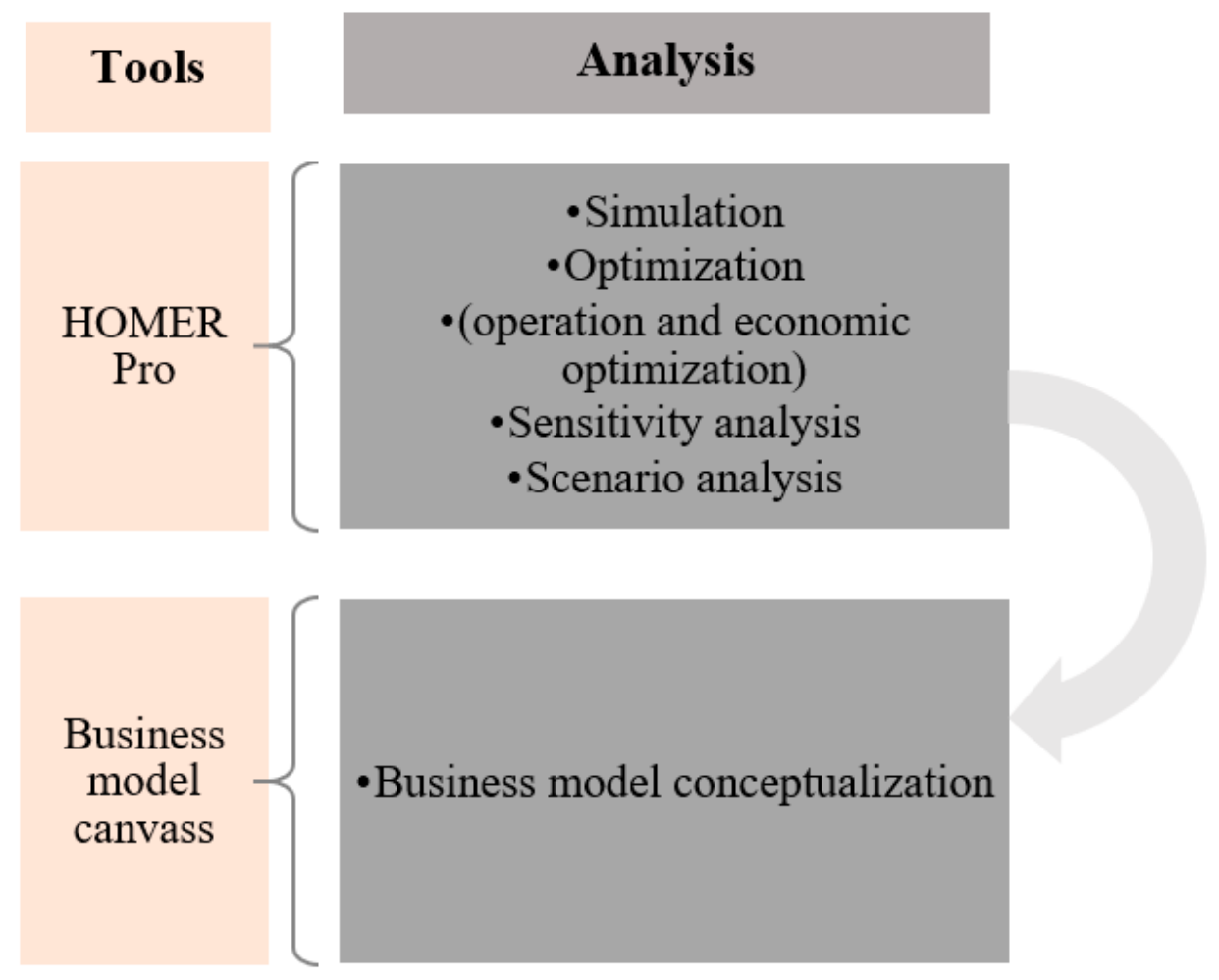

Figure 2. Systematic steps of the overall method (tools and analysis) (source: from the authors).

\subsection{System Components and Input Data}

The analyses required information on the site location, electrical loads, RE resource availability, and technical and economic input data. These data encompassed components' costs (capital, replacement, operation and maintenance) and characteristics (operating hours and lifetime), fuel costs, project economics, dispatch strategies, system constraints, sensitivity values and other specific component properties. Descriptions of the required input data for the HOMER Pro simulations are provided subsequently.

\subsubsection{Location Coordinates and RE Resource Availability}

The required information on location coordinates and available RE resource were obtained from the first step of the IREP framework [11]. Nigeria was selected as a prototypical case study for demonstrating the framework. Two local communities already elicited and adopted in previous studies [24] were considered for this study. They were Giere in Dange Shuni Local Government Area (LGA) of Sokoto state, North-West Nigeria, and Onye-okpon in Obubra Local Government Area (LGA) of Cross-river state, South-East Nigeria. They are predominantly agrarian societies and their main income source include cultivation of food crops and agro-processing applications. HOMER Pro utilized the geographical coordinates to obtain the solar resource (global horizontal irradiance (GHI)) and temperature data based on NASA Surface Meteorology and Solar Energy database (https://catalog.data.gov/dataset/surface-meteorology-and-solar-energy). The biomass resources considered only agricultural crop residues based on indigenous crop production in these localities. The biomass energy potential arrived at $0.59 \mathrm{GWh} /$ year and $2.47 \mathrm{GWh} /$ year for residue availability of $605.74 \mathrm{t} /$ year and $2459.55 \mathrm{t} /$ year for Giere and Onye-okpon, respectively [11]. This provided the average daily residue availability input data as required. The crop residue distribution is shown in Figure 3. 


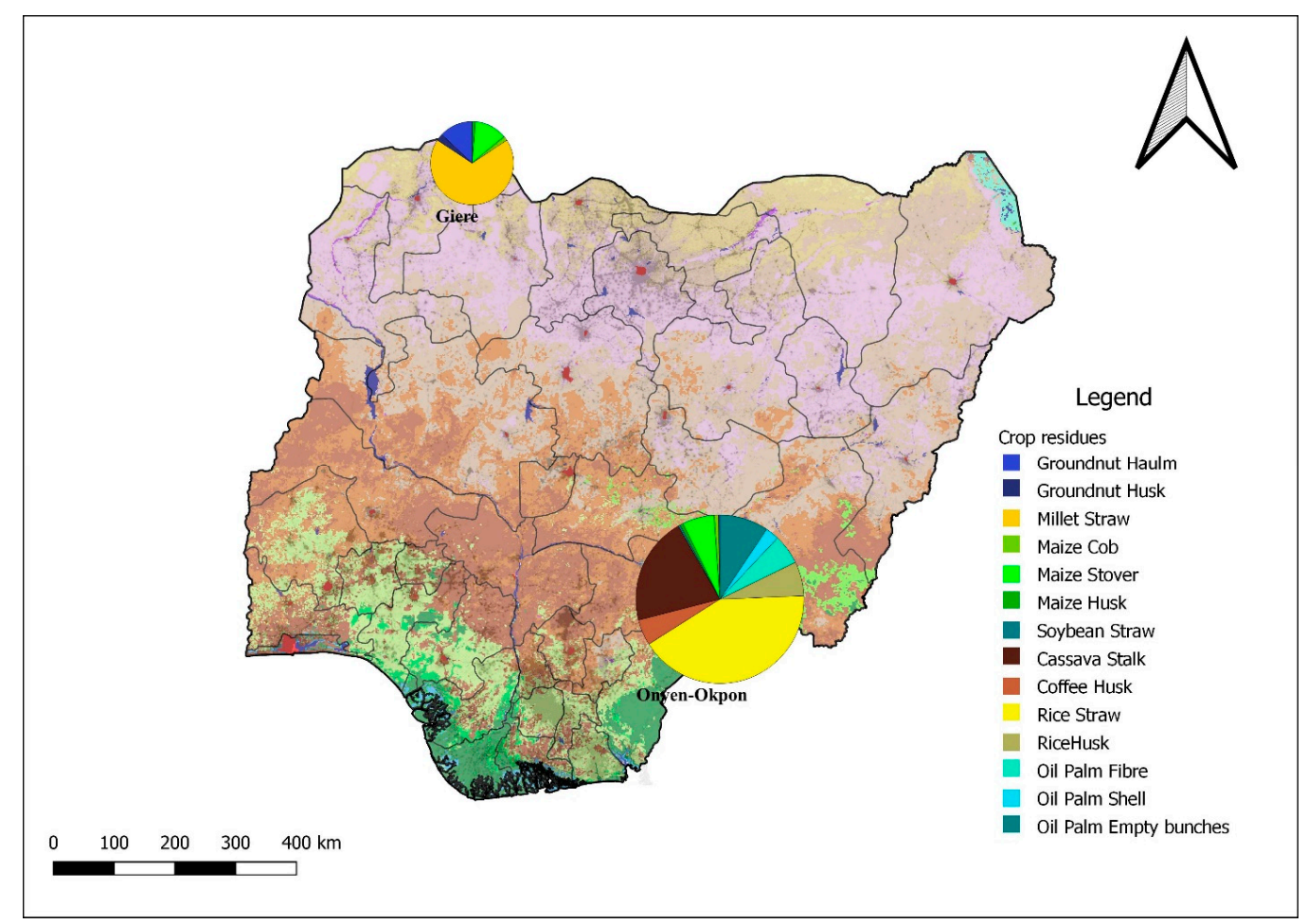

Figure 3. Crop residue distribution (source: from the authors).

\subsubsection{Electrical Loads}

The annual hourly electric load profile that was obtained at disaggregated energy use levels using the reference building approach [23] is shown in Figure 4. This approach is a bottom-up demand estimation approach based on the built environment. It avails a suitable approach for use when there is limited or lack of monitored and measured data as typified by rural areas in most of the developing world. It employs a hybrid approach to obtain physics-based bottom-up engineering building models to compute the energy consumption of identified reference buildings. The profile is disaggregated into lighting, electrical appliances and space cooling. This constituted the community energy demand encompassing diverse sectors with their contributions in varying proportions, as shown in Figure 5. Onye-Okpon represents a medium off-grid site, while Giere represents a small off-grid site. This disparity based on the reference building distribution impacts the overall community demand [69]. The two communities have divergent climatic dispositions and this results in seasonal variations across the load profiles.

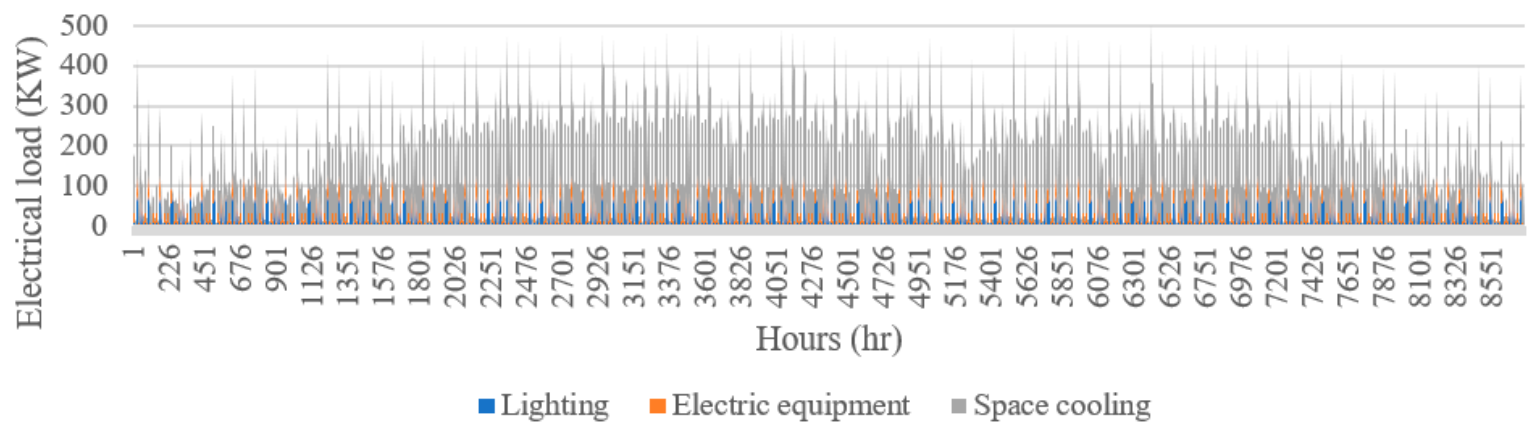

(a)

Figure 4. Cont. 


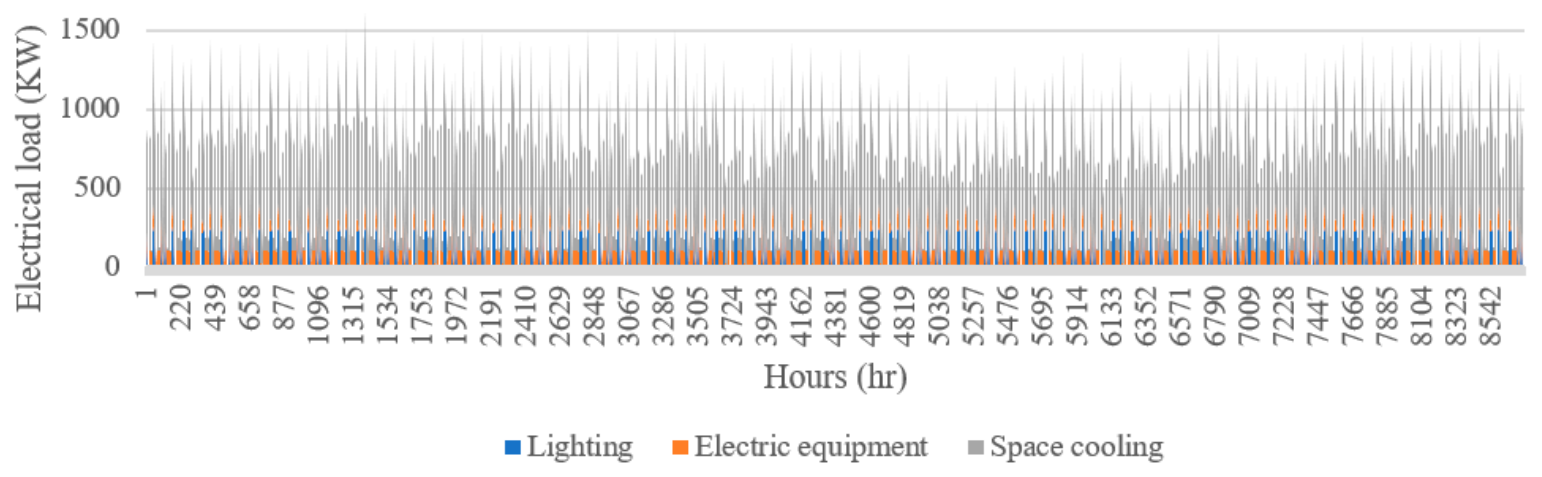

(b)

Figure 4. Electrical load profile for the two communities. (a)Giere load profile, (b). Onye-okpon load profile.

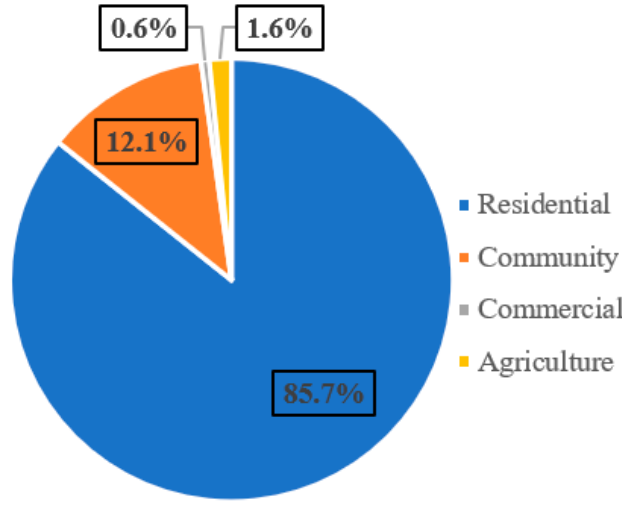

(a)

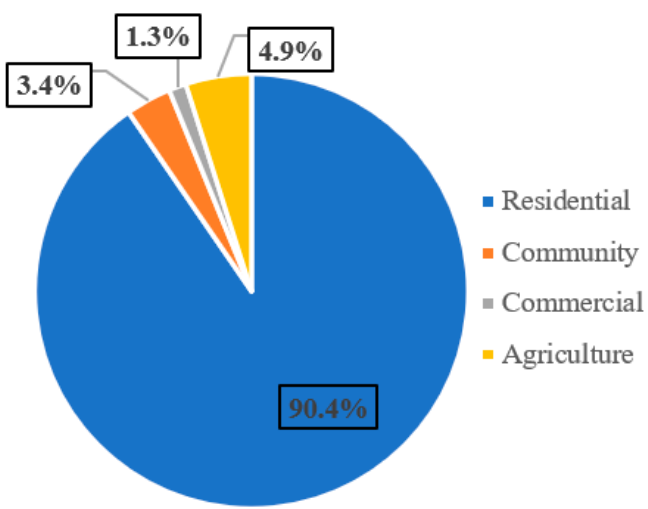

(b)

Figure 5. Sectoral distribution of the electrical load for the two communities (share of community energy demand). (a) Giere, (b) Onye-okpon

\subsubsection{System Components}

The second step in the IREP framework [24] informed the selection of the system components. Therefore, the following components were investigated for the RHMGs: PV module, biomass combined heat and power (B-CHP) plant, diesel internal combustion engine (D-ICE) generator, battery (Lead acid Advanced Storage Module (LA ASM)) and power converter. The technical and economic input data are presented in Tables 1-3.

Table 1. Costs and characteristics of system components.

\begin{tabular}{ccccc}
\hline System Components & Capital Cost $\mathbf{\$} / \mathbf{k W})$ & Replacement Cost $\mathbf{( \$ / k W )}$ & Annual O\&M Cost (\$/year) & Lifetime \\
\hline PV module & $1210^{1}$ & $1077^{2}$ & $10^{6}$ & 25 years ${ }^{6}$ \\
\hline Biomass CHP & See Table $2^{1}$ & See Table ${ }^{3}$ & $\$ 0.10 / \mathrm{h}^{7,8}$ & $20,000 \mathrm{~h}^{6}$ \\
\hline Diesel ICE & See Table $2^{1}$ & See Table $2{ }^{4}$ & $\$ 0.010 / \mathrm{h}^{6}$ & $15,000 \mathrm{~h}^{6}$ \\
\hline Battery (per unit) & $286^{1}$ & $237^{4}$ & $10^{6}$ & 4 years min $^{6}$ \\
\hline Converter & $176^{1}$ & $164^{5}$ & 0 & 15 years $^{6}$ \\
\hline
\end{tabular}

${ }^{1}$ Sum of the equipment costs obtained from literature ([70,71]) and local retail sites $([72,73])$ and the installation cost taken as $10 \%$ of capital cost (only). Replacement cost which is less than the capital costs by ${ }^{2} 11 \%,{ }^{3} 20 \%,{ }^{4} 17 \%$ and ${ }^{5} 7 \%$ [53], ${ }^{6}$ default values in HOMER, ${ }^{7}$ Yimen et al. [45], ${ }^{8}$ Sigarchian et al. [53]. PV, photovoltaic; CHP, combined heat and power; ICE, internal combustion engine. 
Table 2. Costs of diesel-ICE and biomass-CHP generators.

\begin{tabular}{|c|c|c|c|c|c|c|c|c|}
\hline \multicolumn{5}{|c|}{ Local Costs } & \multicolumn{4}{|c|}{ Scaled Costs } \\
\hline & \multicolumn{2}{|c|}{ Diesel-ICE } & \multicolumn{2}{|c|}{ Biomass-CHP } & \multicolumn{2}{|c|}{ Diesel-ICE } & \multicolumn{2}{|c|}{ Biomass-CHP } \\
\hline $\begin{array}{l}\text { Size } \\
(\mathbf{k W})\end{array}$ & $\begin{array}{c}\text { Capital Cost } \\
(\$ / \mathbf{k W})\end{array}$ & $\begin{array}{l}\text { Replacement } \\
\text { Cost }(\$ / k W)\end{array}$ & $\begin{array}{c}\text { Capital Cost } \\
(\$ / \mathbf{k W})\end{array}$ & $\begin{array}{l}\text { Replacement } \\
\text { Cost }(\$ / k W)\end{array}$ & $\begin{array}{c}\text { Capital Cost } \\
(\$ / \mathbf{k W})\end{array}$ & $\begin{array}{l}\text { Replacement } \\
\text { Cost }(\$ / \mathbf{k W})\end{array}$ & $\begin{array}{c}\text { Capital Cost } \\
(\$ / \mathbf{k W})\end{array}$ & $\begin{array}{l}\text { Replacement } \\
\text { Cost }(\$ / k W)\end{array}$ \\
\hline 1000 & 183 & 152 & 2448 & 1958 & 183 & 152 & 2448 & 1958 \\
\hline 750 & 130 & 108 & 2393 & 1915 & 154 & 128 & 2060 & 1648 \\
\hline 500 & 137 & 114 & 2401 & 1921 & 121 & 100 & 1615 & 1292 \\
\hline 400 & 211 & 175 & 2477 & 1981 & 106 & 88 & 1413 & 1130 \\
\hline 300 & 162 & 134 & 2426 & 1941 & 89 & 74 & 1189 & 951 \\
\hline 250 & 139 & 115 & 2402 & 1922 & 80 & 66 & 1066 & 852 \\
\hline 200 & 171 & 142 & 2435 & 1948 & 70 & 58 & 932 & 746 \\
\hline
\end{tabular}

Table 3. Project Economics and fuel costs inputs.

\begin{tabular}{cc}
\hline Project Input & Values \\
\hline Inflation rate (\%) & $11.85^{1}$ \\
\hline Discount rate (\%) & $14^{2,3}$ \\
\hline Annual Capacity shortage (\%) & $0{ }^{2,3}$ \\
\hline Project lifetime (years) & $25^{2,3}$ \\
\hline Diesel price (\$/L) & $0.67^{4}$ \\
\hline Biomass feedstock price (\$/t) & $20^{5}$ \\
\hline${ }^{1}[74],{ }^{2}[75],{ }^{3}[76],{ }^{4}[77],{ }^{5}[78]$. \\
\end{tabular}

When converted, the $\$ / \mathrm{kWh}$ for diesel fuel is $\$ 0.062 / \mathrm{kWh}$, while biomass derived electricity is roughly 17 times lower at $\$ 0.0036 / \mathrm{kWh}$. A generic flat plate PV was adopted with its corresponding characteristics as defined in the HOMER Pro's component library. The PV efficiency was adjusted to $17 \%$ (the average efficiency of commercial PV modules [79]), a derating factor of $80 \%$ (recommended for high temperature regions [80]) was adopted, orientation angles (slope and azimuth) were optimized (based on the PVGIS-CMSAF solar radiation database [81]) to $4^{\circ}$ and $25^{\circ}$ for Onye-okpon, and $16^{\circ}$ and $-1^{\circ}$ for Giere, corresponding the slope and azimuth, respectively. Considerations were made for temperature effects based on the temperature resource data. It should be noted here that the impact of the cost scaling methodology [82] was not applied to the PV plants because the recent reduction in PV costs create a large uncertainty and wide spread in values of the future potential costs. The values of the future costs for PV should thus be treated as extremely conservative and care must be taken in comparing them to those for the B-CHP and D-ICE plants.

The B-CHP plant consisted of a downdraft gasifier (the downdraft gasifier is the recommended technology for small-scale biomass power generation [83-85]) with a generic reciprocating engine (co-generative ICE; are the revered generator choice for small-scale biomass electricity generation systems $[32,84,86])$ genset, which was considered to operate as a single unit. Biomass gasification was the recommended energy conversion technology for crop residues as biomass feedstock $[42,83,84,87]$. The combination of gasification and reciprocating engines (B-CHP) enables an enhanced process efficiency (a higher electrical efficiency) especially for small-scale electricity generation systems $[42,84,88]$. A generic D-ICE generator was adopted for this study. For the B-CHP and D-ICE generators, the capital and replacement costs considered both the local costs (local vendor supplied quotes) [72,73] and the scale costs (based on the capital cost scaling methodology and adopted the quote for a similar plant using equations that typically employ at least one process parameter and an exponent to account for economies of scale) [82]. This is shown in Table 2. For both gensets, a minimum load ratio of $30 \%$ was considered [44,53], while their respective fuel costs are provided in Table 3. The generic lead acid battery, which considered the modified kinetic battery model, was adopted. The modified kinetic 
battery model considers rate dependent losses, temperature dependence on capacity temperature effects on calendar life and estimates battery cycle lifetime [66]. The minimum state of charge and degradation limit were set to $40 \%$ [89]. A generic system converter was adopted with its corresponding characteristics as defined in the HOMER Pro's component library. The constant currency approach which incorporates an adjustment for inflation [90] was adopted for the economic analysis based on the discount rate and other project economics data in Table 3.

\subsection{Sensitivity Analysis}

Sensitivity analysis was performed by varying design variables as presented in Table 4 . This was done to evaluate their influence on the cost effectiveness of different system configurations and ultimately identify variables that have significant impact on the design and operation of the RHMG systems.

Table 4. Sensitivity values.

\begin{tabular}{cc}
\hline Sensitivity Variables & Values \\
\hline Discount rate $(\%)$ & $12,14,16,18,20$ \\
\hline Capacity shortage $(\%)$ & $0,2,4,6,8,10$ \\
\hline Diesel price $(\$ / \mathrm{L})$ & $0.57,0.67,0.77,0.87,0.97,1.07,1.17$ \\
\hline Biomass feedstock price $(\$ / \mathrm{t})$ & $20,30,40,50,60,70$ \\
\hline PV cost $(\$ / \mathrm{kW})$ & $710,1210,1710,2210,2710$ \\
\hline Battery Cost $(\$ /$ unit $)$ & $86,186,286,386,486$ \\
\hline
\end{tabular}

\subsection{Scenario Analysis: DSM Considering Energy Efficiency Measures}

The DSM functionality based on energy efficiency was associated with demand reduction and financial design optimization which sought to investigate the cost-effectiveness of efficiency measures and the ensuing economic benefits in terms of financial parameters outputs [31]. Using scenario analysis with HOMER Pro, this could be done using the multi-year module scheme (this incorporates an average yearly percentage reduction in the load based on a given scenario assumption) or efficiency (advanced) function of the advanced load module [66]. The advanced load module considers the investment cost and lifetime of the energy efficiency measures coupled with the demand reduction multiplier or annual hourly load profile of the scenarios considered, namely, advanced retrofit-IEQ ${ }_{\text {I }}$ advanced retrofit-IEQ II and advanced retrofit-IEQ III. These have been performed from the first step of the IREP framework and are incorporated into the analysis. These scenario were developed according to adaptive comfort strategies for indoor environment quality and building retrofit \& energy efficiency [11].

\subsection{Business Model Conceptualization: The Business Model Canvas Tool}

The BMC is an analytical and conceptual tool used to identify key components or constructs that can inform the successful deployment of the RHMGs and avail support for incorporating complementary actions such as the uptake of energy efficiency measures for DSM. This involves analyzing real life cases $[91,92]$ and business model patterns in existing literature $[29,58,59,67,68]$ to draw insights on the local value chain/supply chain and co-create market services to invigorate the local economy in these communities. The BMC shown in Figure 6 provides a simple, relevant and intuitively understandable tool to describe a business model, providing linkages between its strategy and unique value proposition [67]. 


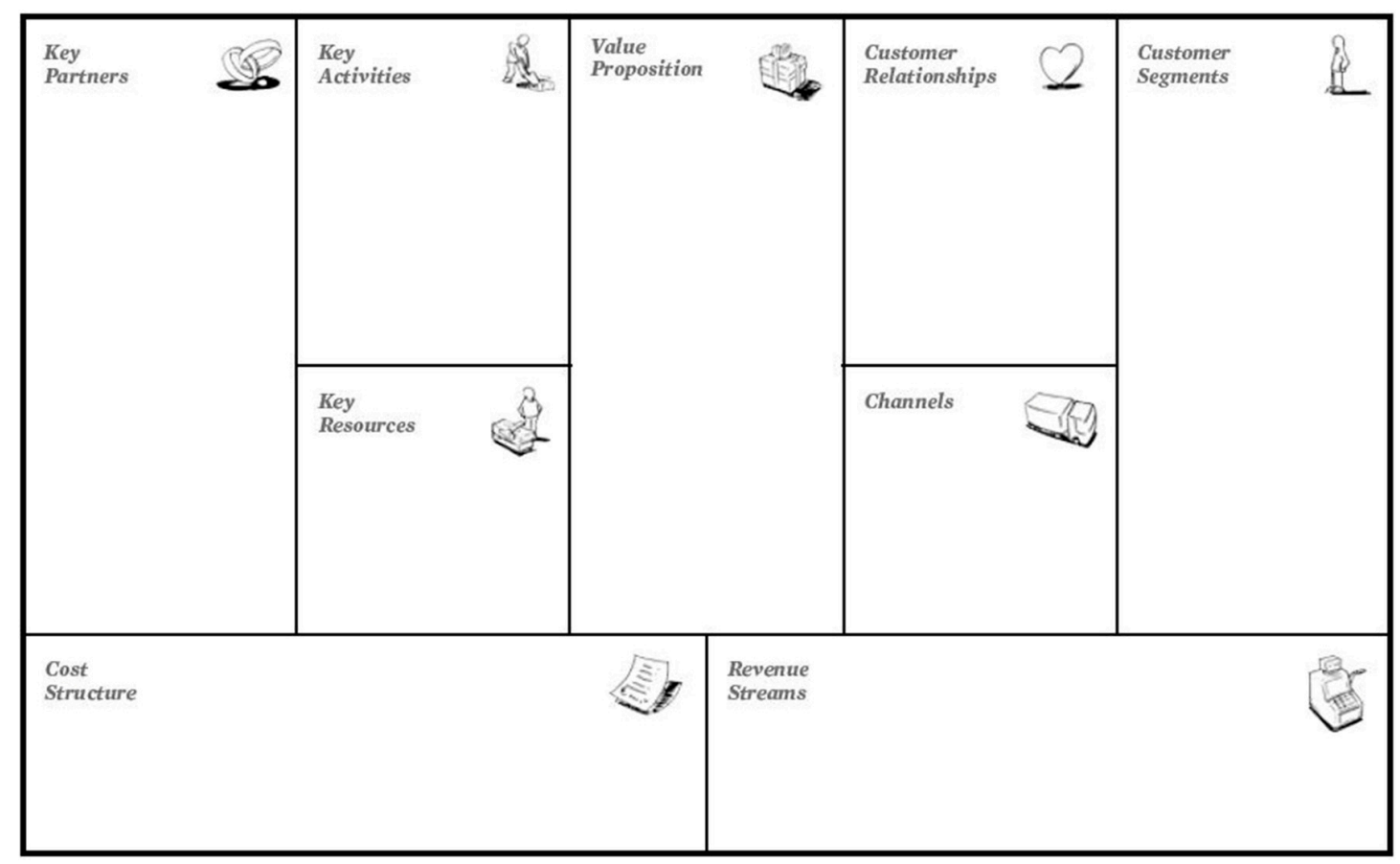

Figure 6. The Business Model Canvas [67].

\section{Results and Discussion}

\subsection{The Optimal System Configuration of the RHMGs}

The simulation analysis produced several distinct energy systems for Giere and Onye-okpon, respectively, from which the optimal systems were selected as the most feasible economic options with the least emissions. The architecture depicting the configuration and sizing of system components for the optimal RHMG systems is presented in Figure 7 with the corresponding component details in Table 5 for the two communities. The monthly electricity production for both communities is shown in Figure 8 as a function of energy source.

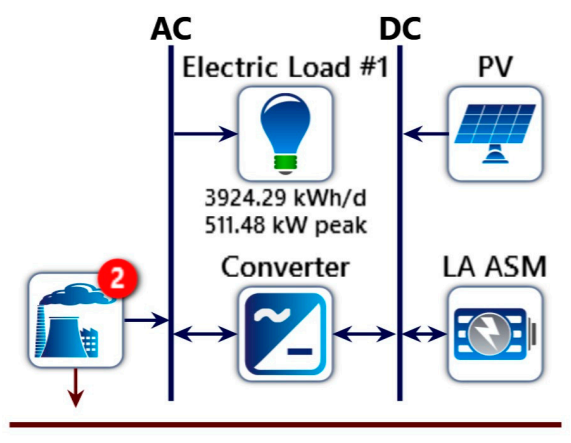

(a)

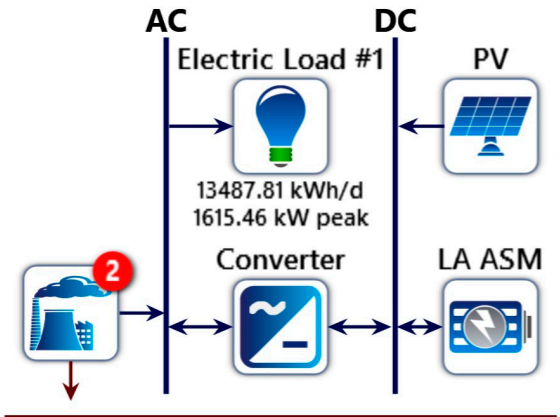

(b)

Figure 7. Schematic diagram of the optimal system architecture, (a) Giere, (b) Onye-okpon. 
Table 5. Simulated optimal system architecture for Giere and Onye-okpon renewable hybrid mini-rids (RHMGs).

\begin{tabular}{ccccc}
\hline & \multicolumn{2}{c}{ Local Current Costs } & \multicolumn{2}{c}{ Scaled Costs for } \\
& B-CHP and D-ICE Plants \\
\hline System Architecture & 428 & Onye-Okpon & Giere & Onye-Okpon \\
\hline PV $(\mathrm{kW})$ & 200 & 1144 & 54.5 & 48.2 \\
\hline Biomass $\mathrm{CHP}(\mathrm{kW})$ & 500 & 600 & 400 & 600 \\
\hline Diesel ICE $(\mathrm{kW})$ & 1320,1354 & 3388,3476 & 256,272 & 714,732 \\
\hline Battery (number of units, $\mathrm{kWh})$ & 163 & 691 & 340 & 280 \\
\hline Converter $(\mathrm{kW})$ & &
\end{tabular}

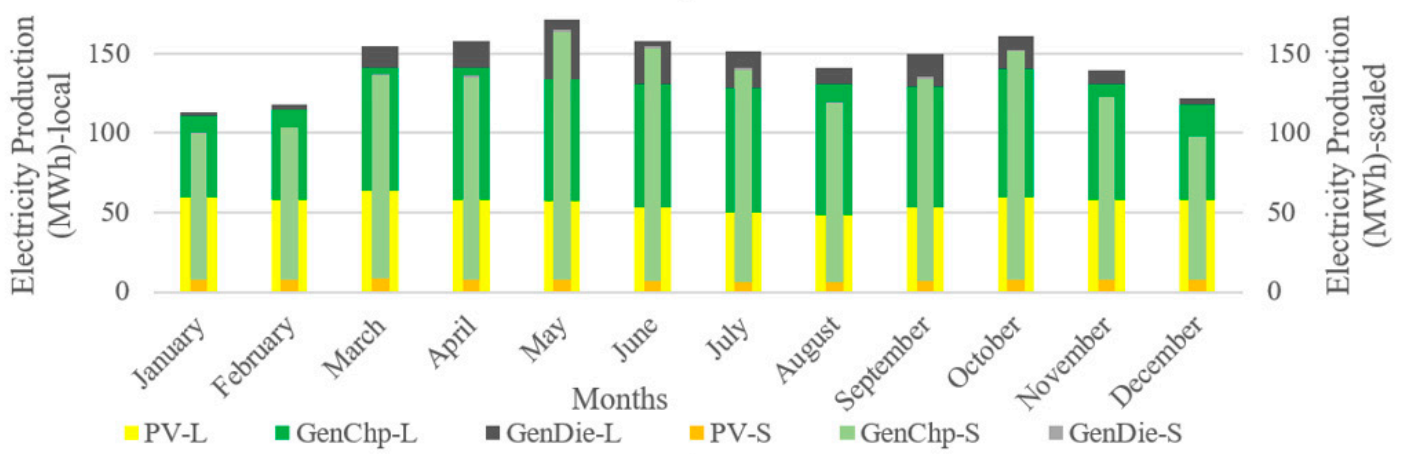

(a)

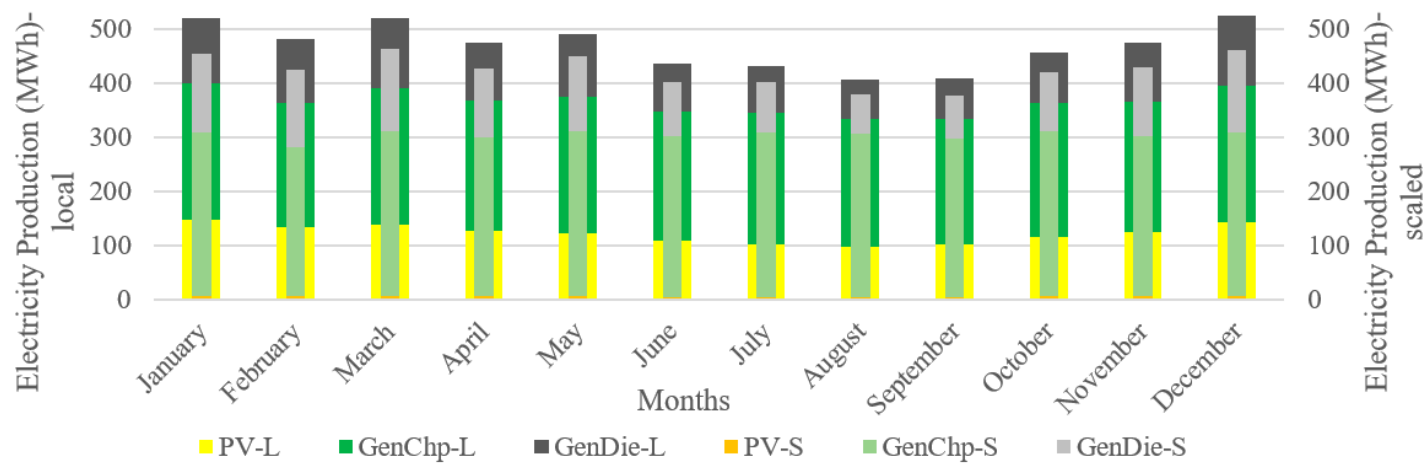

(b)

Figure 8. Monthly electricity production as a function of energy source. (a) Giere's monthly electricity production, (b) Onye-okpon's monthly electricity production.

The B-CHP (GenChp) plant has emerged as a dominant generation option across the two communities irrespective of the capital cost adopted. It accounts for the highest annual electricity production across the different optimal RHMG systems. The use of current proven local costs favored the adoption of PV over D-ICE (GenDie) generator for electricity production across both communities. However, with the scaled costs, which captures the significance of scale economies with plant capacity, the D-ICE generator is prioritized over the PV generator (which was not scaled) for Onye-okpon, while reverse is the case for Giere. Onye-okpon has a higher electrical load than Giere and this load disparity ultimately translates to an advantageous economy of scale for the optimal RHMG system. This plays a critical role in the implementation and deployment of these systems at nationwide scales and could improve the optics in terms of efficient resource allocation and distribution. Ultimately, these results buttress the need to further evaluate the intricacies and modalities of utilizing the biomass 
gasification technology for rural electrification if it can reach appropriate scale to compete with PV at the current scale.

For both communities, carbon dioxide accounts for the bulk of the greenhouse gas (GHG) emissions to approximately $99 \%$ of the total emissions. The performance of these systems in terms of the economic and environmental modalities are presented in Table 6 and the cost breakdown in Figure 9.

Table 6. Economic and environmental metrics for optimal RHMG system performances for Giere and Onye-okpon.

\begin{tabular}{|c|c|c|c|c|c|}
\hline \multicolumn{2}{|c|}{ System Performance } & \multicolumn{2}{|c|}{ Local Current Costs } & \multicolumn{2}{|c|}{$\begin{array}{c}\text { Scaled costs for B-CHP and } \\
\text { D-ICE Plants }\end{array}$} \\
\hline & stem Metrics & Giere & Onye-Okpon & Giere & Onye-Okpon \\
\hline \multirow{6}{*}{ Economic Metrics } & Annual worth (\$/year) & 282,675 & 365,809 & 355,116 & 50,592 \\
\hline & Net Present Cost (\$) & $4,825,979$ & $15,979,370$ & $952,143.90$ & $7,140,220$ \\
\hline & Return on investment (\%) & 21.6 & 12.0 & 139.1 & 17.3 \\
\hline & Internal Rate of Return (\%) & 26.6 & 15.8 & 147 & 22.9 \\
\hline & Simple payback (year) & 4.05 & 5.81 & 0.674 & 4.14 \\
\hline & Discounted payback (year) & 4.22 & 6.17 & 0.69 & 4.39 \\
\hline
\end{tabular}

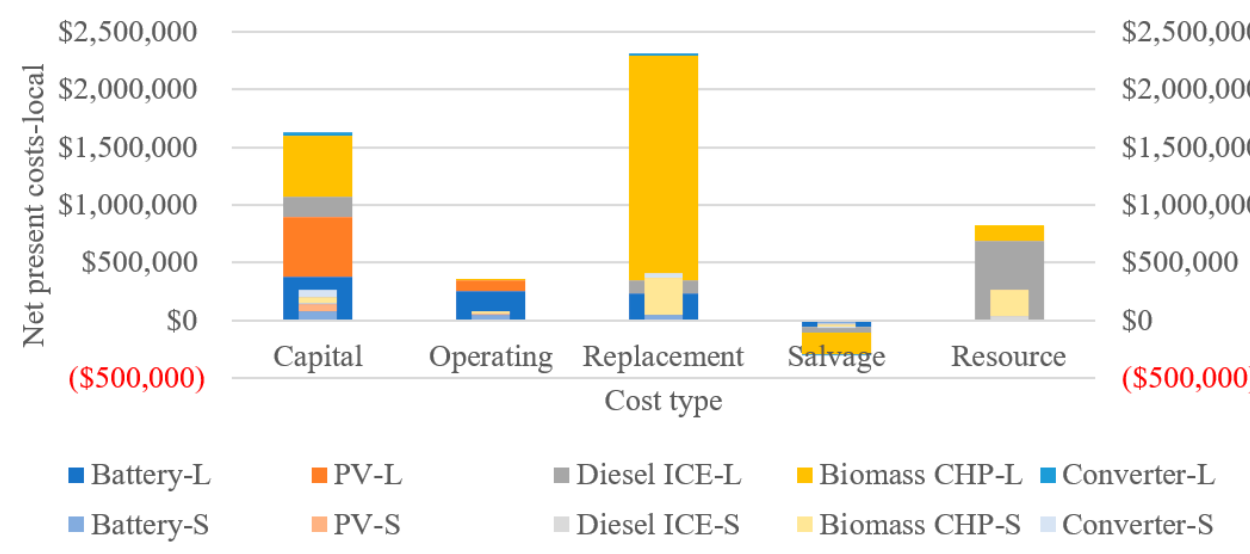

(a)

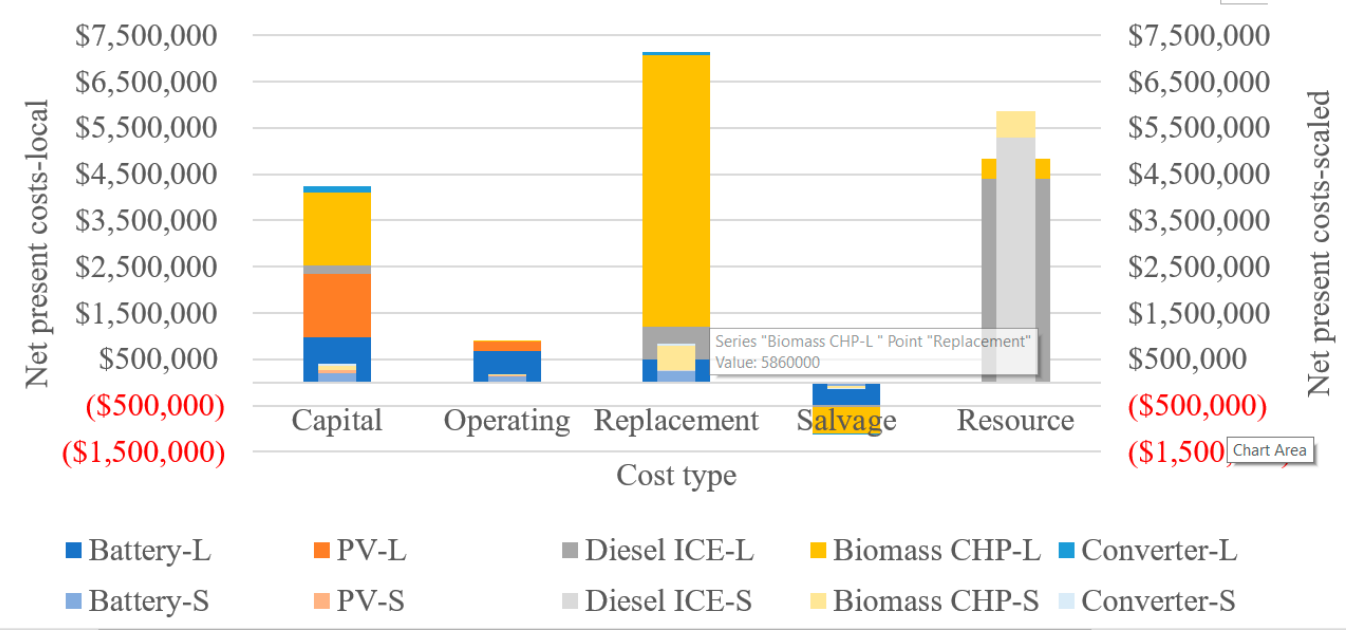

(b)

Figure 9. Net present costs (NPC) breakdown for both communities. (a) Giere (L-local costs and S-scales costs for B-CHP and D-ICE plants), (b) Onye-okpon (L-local costs and S-scales costs for B-CHP and D-ICE plants). 
The observed pattern of the cost breakdown is consistent for both communities such that from the component perspective the biomass CHP plant accounts for the bulk of the NPC. This is attributed to the capital and replacement costs, which account for the bulk of the NPC from the cost type perspective. The LCOE range arrived at $\$ 0.0337-0.171 / \mathrm{kWh}$ across both communities. This is reasonably comparable to the typical distribution companies (DISCOs) electricity tariff in Nigeria in the range of $\$ 0.069-0.16 / \mathrm{kWh}[9,93]$ and is less expensive than the tariff of operational mini-grids in the country in the range of $\$ 0.40-\$ 1.00 / \mathrm{kWh}[69,94]$. These results raise optimism for attracting investments as these communities have already been identified low-hanging fruits [11]. They represent locations where infrastructure and human capacities coupled with other local expertise exist [14]. However, the impact of these exisitng infrastructure (local distribution network) have not been captured in these results. The positive values of economic metrics such as the present worth (PW), annual worth (AW), the Internal Rate of Return (IRR), the return on investment (ROI) and payback periods (PBs) attest to the viability of the projects and help gauge the profitability of the investments especially in the absence of capital incentives from the Government [95]. This position has been reiterated by other studies, a discounted payback period of 6 years was computed for the optimal RHMG with similar system composition [44], while the IRR of $23 \%$ and a simple payback period between 4 and 5 years were estimated for another optimal RHMG with similar system composition [46].

\subsection{Sensitivity Results}

The sensitivity results obtained with surface plots graphs are shown in Figures 10-12. The surface plot avails a graphical representation of sensitivity results to view how the value of two result variables changes over the range of two sensitivity variables [66]. These results show the dependence of system performance variables (NPC and LCOE) on the sensitivity variables (see Table 4). The sensitivity variables are represented on the main axes; one system performance variable is plotted as the result variable with the other is the superimposed variable.

Across both communities and the adopted capital costs, the NPC and the LCOE are sensitive to the discount rate (DR) and slightly sensitive to the capacity shortage (CS). The NPC decreases while the LCOE increases with DR. The NPC and the LCOE are more sensitive to the diesel price (DP) than the biomass price (BP) for Onye-okpon, irrespective of adopted capital costs. For Giere, the NPC and the LCOE are more sensitive to the BP than the DP especially with the scaled capital costs. The NPC and LCOE increase with increase in the respective fuel price. The NPC and LCOE are sensitive to the PV cost (PC) and the battery cost (LA ASM) and increase with the PC and LA ASM. The PV costs could be reduced by increased technical development in PV modules (e.g., black silicon [96]), continued economics of scale and the learning rate [97-99], and reduced BOS costs through innovative racking [100]. Overall, the significant sensitivity variables, which could deem critical design variables, are discount rate, fuel prices, PV and battery costs. Their degree of sensitivity on both LCOE and NPC is adopted to rank the variables in order of decreasing significance. The fuel prices are the most significant design variables across the two communities.

The discount rate, PV and battery costs also exert significant influence on both LCOE and NPC contingent on the optimal system generation mix and their electricity production. For Giere that favors the PV and B-CHP generating systems; the PV and battery costs are more significant design variables than the discount rate. For Onye-okpon, which favours D-ICE and B-CHP generating systems, this trend is reversed as the discount rate is more influential on system economics. Overall, for implementation of the RHMGS, strategically maneuvering these design variables could avail reductions in the LCOE and NPC without compromising the integrity, reliability and viability of the system. The insights from the sensitivity analysis would be very useful in designing and customizing robust business models especially for mapping revenue streams and cost structures. This will inform efficient resource planning and management especially in the event limited or seasonal availability of resources. 


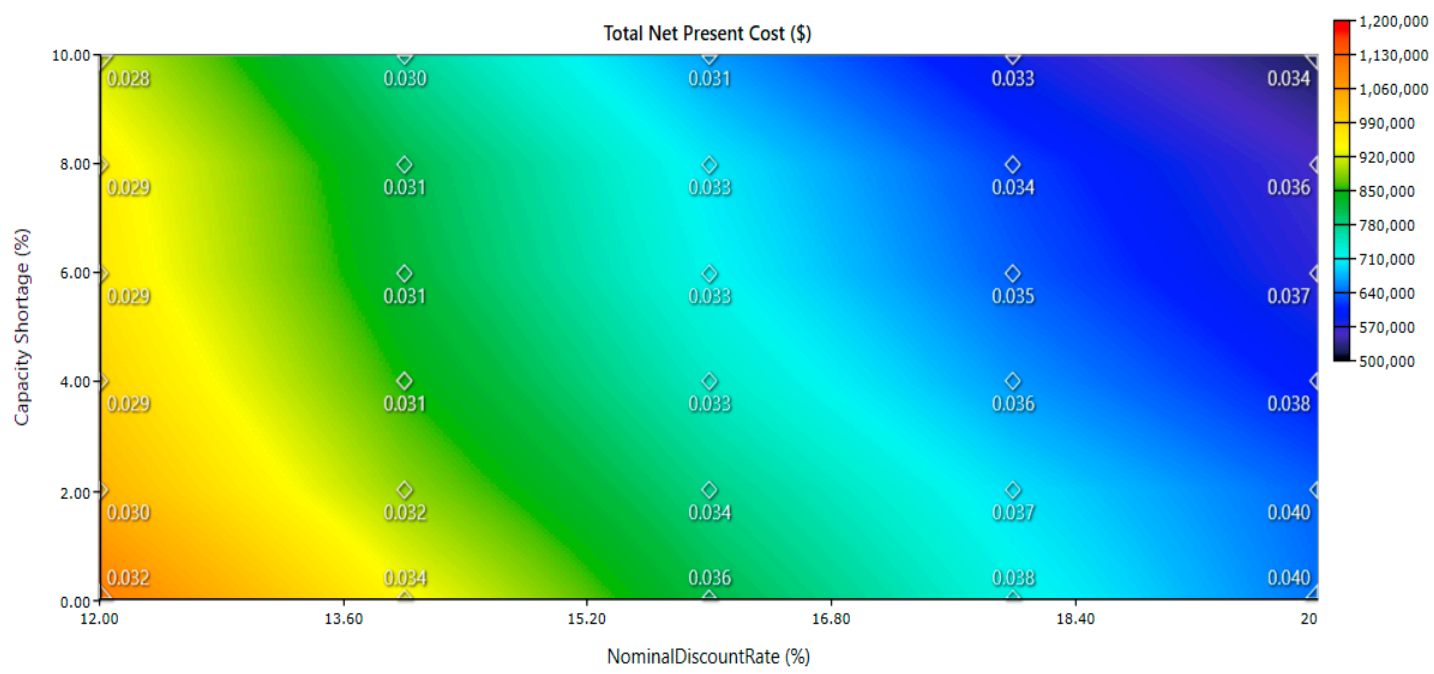

(a)

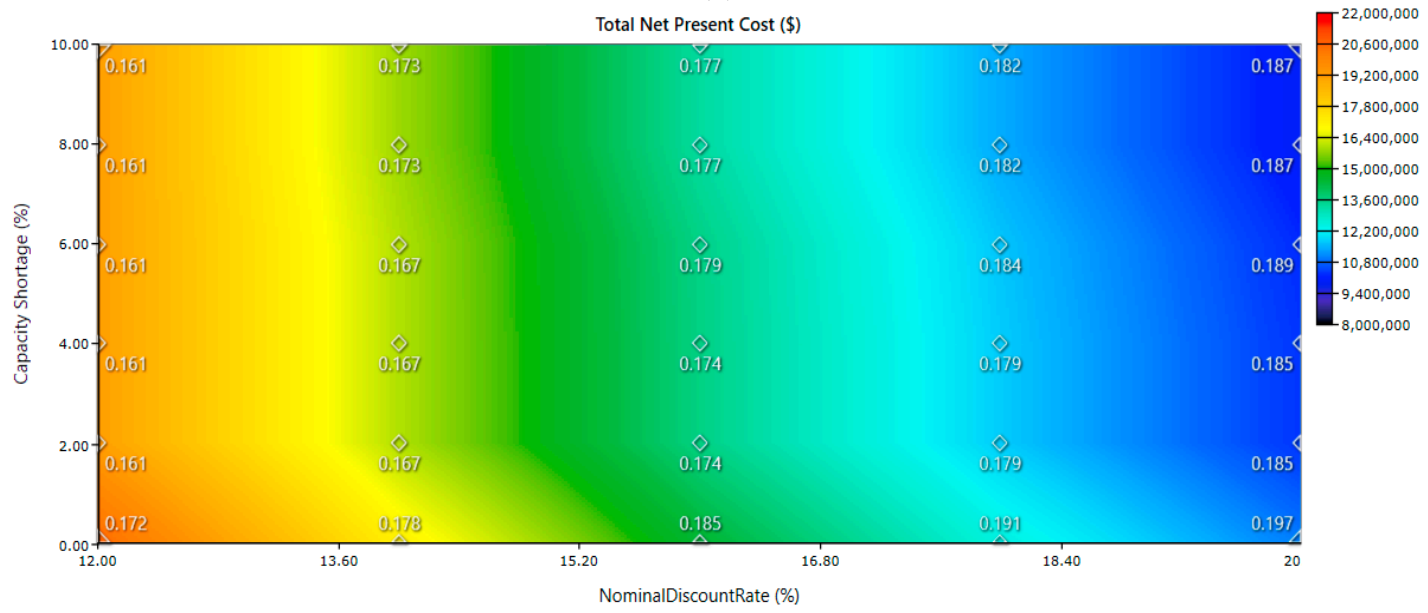

(b)

Figure 10. Surface plots for discount rate (DR) and capacity shortage (CS) sensitivity on NPC and levelized cost of electricity (LCOE). (a) Giere (scaled costs for B-CHP and D-ICE plants): surface plots for discount rate (DR) and capacity shortage (CS), (b) Onye-okpon (local current costs): surface plots for discount rate (DR) and capacity shortage (CS).

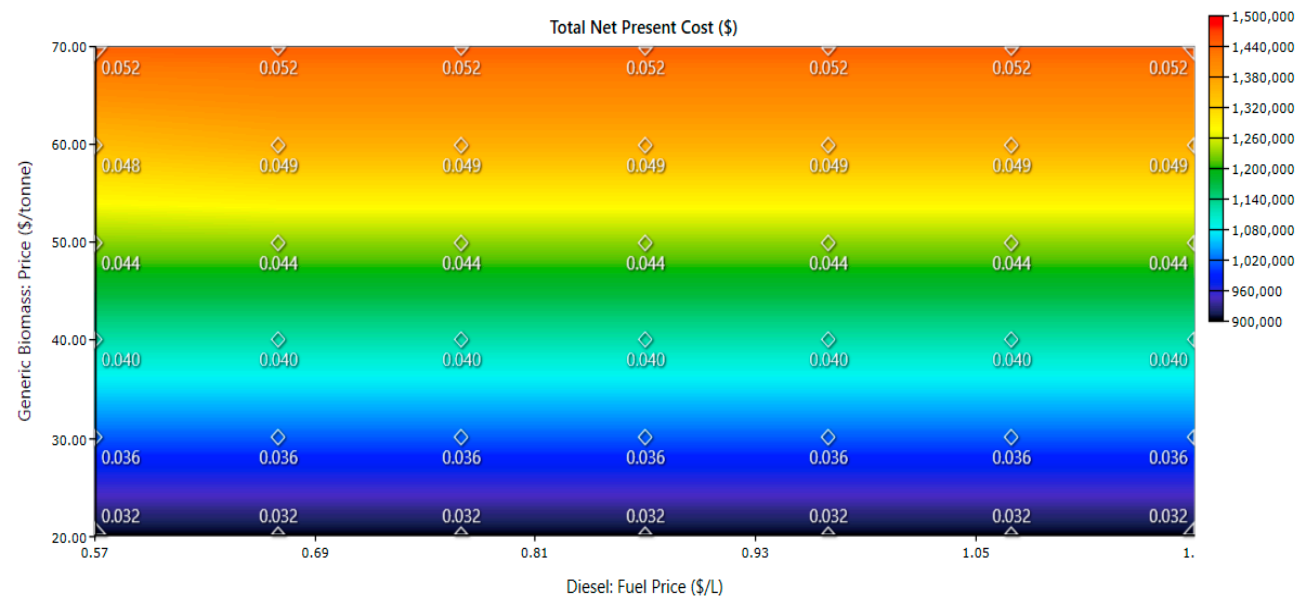

(a)

Figure 11. Cont. 


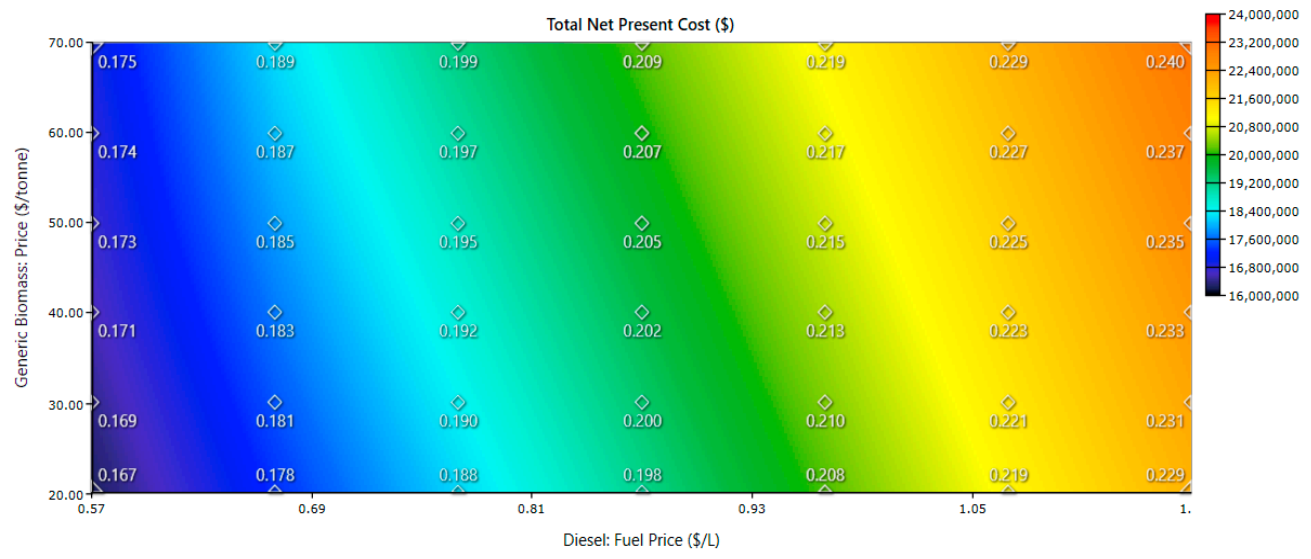

(b)

Figure 11. Surface plots for diesel price (DP) and biomass price (BP) sensitivity on NPC and LCOE. (a) Giere (scaled costs for B-CHP and D-ICE plants): surface plots for diesel price (DP) and biomass price (BP), (b) Onye-okpon (local current costs): surface plots for diesel price (DP) and biomass price (BP).

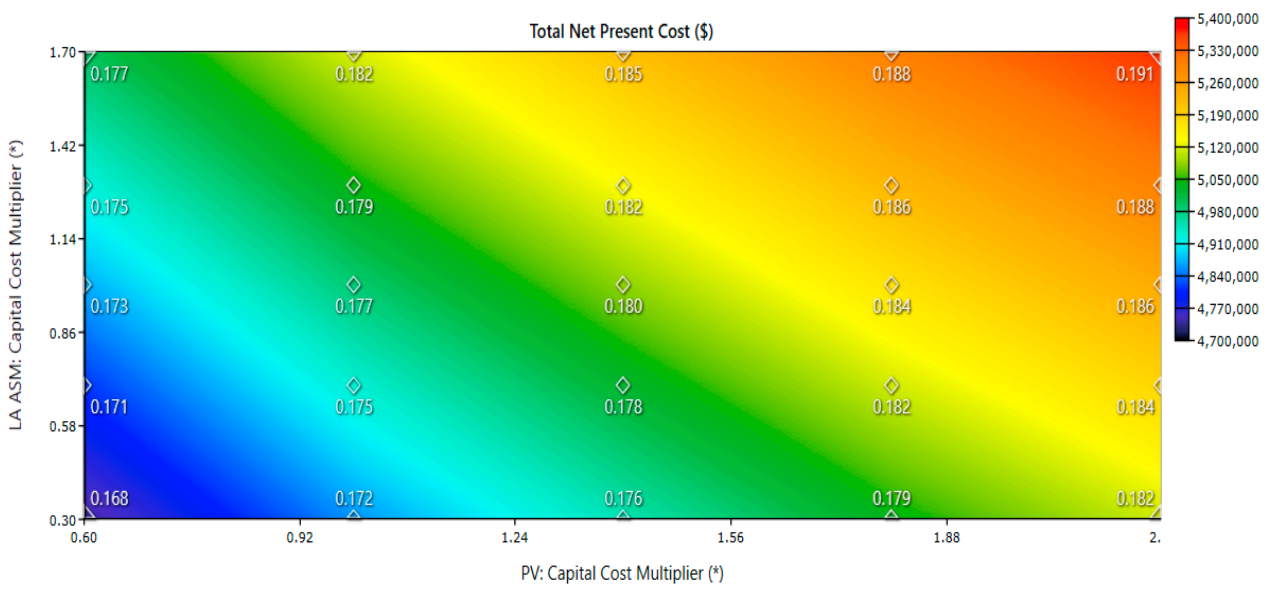

(a)

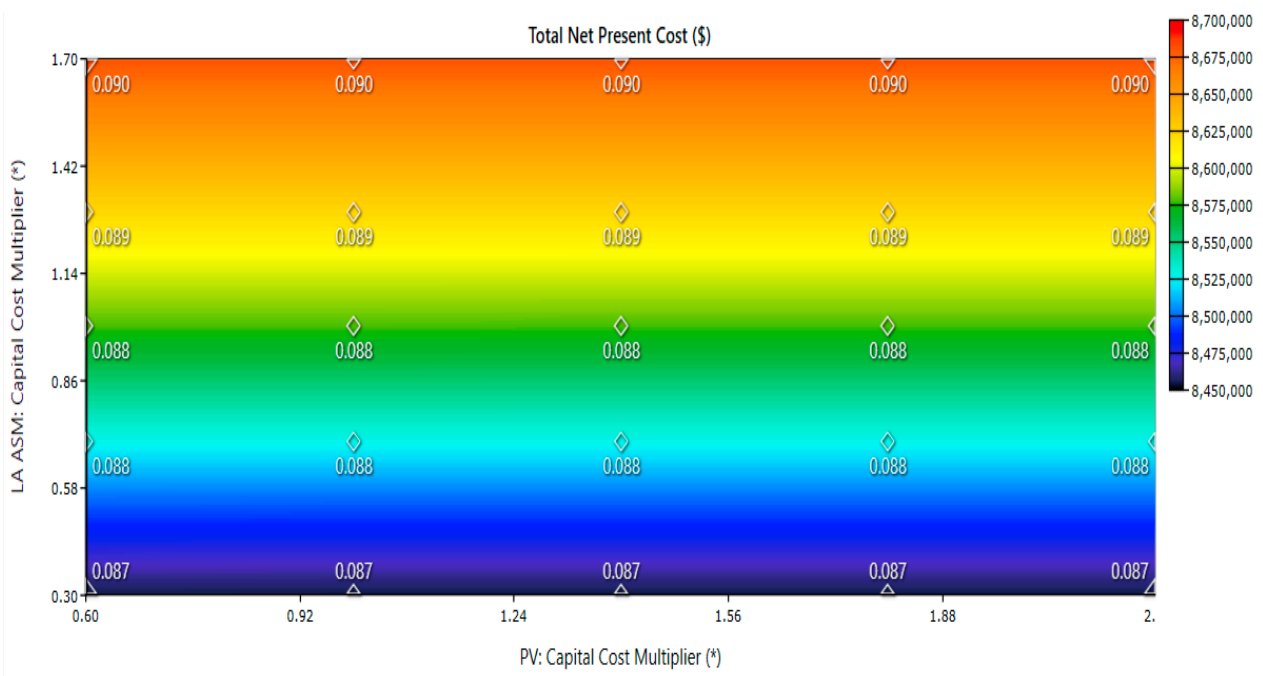

(b)

Figure 12. Surface plots for PV capital cost (PC) and battery capital cost (LA ASM) sensitivity on NPC and LCOE. (a) Giere (local current costs): surface plots for PV capital cost (PC) and battery capital cost (LA ASM), (b) Onye-okpon (scaled costs for B-CHP and D-ICE plants): surface plots for PV capital cost (PC) and battery capital cost (LA ASM). 


\subsection{Scenario Analysis Results}

The performance and cost curtailment potential of the DSM scenarios were investigated, and the results are presented in Tables 7 and 8.

Table 7. Scenario analysis results (with local current costs).

\begin{tabular}{|c|c|c|c|c|c|c|c|}
\hline \multirow{2}{*}{\multicolumn{2}{|c|}{ System Performance }} & \multicolumn{3}{|c|}{ Giere } & \multicolumn{3}{|c|}{ Onye-Okpon } \\
\hline & & DSM 1 & DSM 2 & DSM 3 & DSM 1 & DSM 2 & DSM 3 \\
\hline \multirow{8}{*}{ Economic Metrics } & PW (\$) & 4017,752 & 3961,508 & 3998,570 & 6333,980 & 7965,437 & 7999,461 \\
\hline & $\mathrm{AW}(\$ /$ year $)$ & 203,917 & 201,062 & 202,943 & 321,474 & 404,277 & 406,004 \\
\hline & NPC (\$) & 3207,559 & 2991,296 & 2891,374 & $13,489,010$ & 7524,564 & 7558,306 \\
\hline & LCOE $(\$ / k W h)$ & 0.174 & 0.192 & 0.212 & 0.154 & 0.153 & 0.151 \\
\hline & ROI (\%) & 25.2 & 25.0 & 24.4 & 18.2 & 26.2 & 26.8 \\
\hline & IRR (\%) & 30.3 & 31.8 & 30.3 & 23.9 & 34.4 & 33.5 \\
\hline & Simple payback (year) & 2.72 & 2.77 & 2.92 & 2.80 & 2.53 & 2.43 \\
\hline & Discounted payback (year) & 2.84 & 2.89 & 3.03 & 2.88 & 2.65 & 2.54 \\
\hline \multirow{2}{*}{ Environmental metrics } & Total emissions (kg/year) & $25,387.35$ & 242.91 & 42.63 & $768,901.90$ & $246,567.00$ & $220,197.68$ \\
\hline & Renewable fraction (\%) & 96.7 & 100 & 100 & 77.9 & 87.9 & 89.2 \\
\hline
\end{tabular}

Table 8. Scenario analysis results (with scaled costs for B-CHP and D-ICE plants).

\begin{tabular}{|c|c|c|c|c|c|c|c|}
\hline \multirow{2}{*}{\multicolumn{2}{|c|}{ System Performance }} & \multicolumn{3}{|c|}{ Giere } & \multicolumn{3}{|c|}{ Onye-Okpon } \\
\hline & & DSM 1 & DSM 2 & DSM 3 & DSM 1 & DSM 2 & DSM 3 \\
\hline \multirow{8}{*}{ Economic Metrics } & PW (\$) & 4859,128 & 4705,980 & 4604,969 & 2235,250 & $10,772,310$ & $10,252,140$ \\
\hline & $\mathrm{AW}(\$ /$ year $)$ & 246,620 & 238,847 & 233,720 & 113,448 & 546,737 & 520,336 \\
\hline & NPC (\$) & $623,681.90$ & $504,322.90$ & $542,473.90$ & 4986,712 & 1215,084 & 1803,025 \\
\hline & LCOE (\$/kWh) & 0.0338 & 0.0323 & 0.0398 & 0.0569 & 0.0247 & 0.0361 \\
\hline & ROI (\%) & 224.6 & 813.4 & 704.8 & 66.1 & 304.6 & 222.2 \\
\hline & IRR (\%) & 238.4 & 844.1 & 732.2 & 69.8 & 319.5 & 232.4 \\
\hline & Simple payback (year) & 0.42 & 0.12 & 0.14 & 1.45 & 0.31 & 0.43 \\
\hline & Discounted payback (year) & 0.42 & 0.12 & 0.14 & 1.49 & 0.32 & 0.44 \\
\hline \multirow{2}{*}{ Environmental metrics } & Total emissions (kg/year) & 87.37 & $23,544.00$ & $33,509.62$ & $708,462.10$ & 6476.58 & $134,929.78$ \\
\hline & Renewable fraction (\%) & 100.0 & 96.5 & 94.5 & 79.2 & 99.7 & 93.0 \\
\hline
\end{tabular}

Overall, with the current local costs, the DSM scenarios provided reductions in varying degrees on the NPC ( $16 \%$ to $53 \%$ reduction across both communities) and total emissions (13\% to $100 \%$ reduction across both communities) in comparison with the optimal system performance (see Table 6). The reductions also resonated additional benefits in increments of the renewable fraction across both communities such that for some scenarios, $100 \%$ renewable electricity production was deemed achievable. With the scaled costs for B-CHP and D-ICE plants, higher NPC reductions were achievable (30\% to $83 \%$ across both communities), but at the cost of increased emissions which was the case for Giere. Recalling that the PV costs were not identically scaled because of the uncertainty, the B-CHP and D-ICE plants are not competitive with PV without scale and only possibly competitive with scaling for communities with larger loads. Therefore, there is the need to apply the economy of scale advantage with caution in modeling especially for the design of small-scale RHMGs. Therefore, the LCOE metric by itself may not be appropriate to assess the cost-effectiveness and viability of these DSM scenarios [57]. However, the obtained results demonstrate the benefits of including energy efficiency from the demand side in terms of investments metrics. 


\subsection{Conceptualized Business Model}

The conceptual business model is shown in Table 9. The value propositions incorporate other valuable additional services to the provision of reliable and secure local electricity access. It buttresses Energy efficiency as a Service (EaaS), the co-creation of a local energy market to support a biomass feedstock supply chain and capacity building and training of local workforce. EaaS takes cognisance of the results for the DSM scenario analysis, which affirms energy efficiency (EE) as a viable demand and cost curtailment strategy. This also targets productive uses of energy that have been captured in the overall load. A local energy market would help orient the biomass feedstock supply chain with additional ripple effects as value streams that can stimulate the local economy. The trained local workforce can then be engaged for feedstock handling, preparation and processing, implementing the EE measures and overall running and day to day operation of the RHMGs, thus, providing opportunities for employment, income generation and sustainable livelihoods. Potential revenue streams that could be direct or indirect dividends of the deployment of these systems could include the payment of a connection to the local grid, 'end-use' or 'service'-based tariff that considers disparities between different customer segments and the availability of subsidies coupled with the sale of bio-gasification by-products that can be channeled to other productive uses [88]. In the advent of interconnecting to the grid, provision of ancillary grid balancing services can be another revenue stream. The cost structure would be such that encompass the different cost components affiliated with the planning, deployment, operation and maintenance of the RHMGs. The key partners envisaged could include local communities for supply of the biomass resources coupled with the facilitating customer relationships and communication channels. Utility companies (DISCOs) could facilitate seamless revenue collection supported by local operators and perform routine system repair, maintenance and servicing, while the original equipment manufacturer (OEM) could support the supply of reliable system components and spare parts with trainings on equipment handling. Government parastatals/relevant ministries (Rural Electrification Agency (REA), Federal Ministry of Agriculture and Rural Development (FMARD)) could provide supportive and enabling policies and strategies to incentivize investors such as tax waivers, import duties, etc. [69]. These partnerships would be invested in the other segments of the key activities and ultimately foster a local sharing economy that can revolutionize the burgeoning mini-grid industry in Nigeria. 
Table 9. The conceptual business model.

\begin{tabular}{|c|c|c|c|c|}
\hline Key Partners & Key Activities & Value Propositions & $\begin{array}{c}\text { Customer } \\
\text { Relationships }\end{array}$ & Customer Segments \\
\hline \multirow{3}{*}{$\begin{array}{ll}\text { - } & \begin{array}{l}\text { Local communities } \\
\text { - }\end{array} \\
\text { lo-operative societies and } \\
\text { - } & \text { Utilities (DISCOs) } \\
\text { - } & \text { Original equipment } \\
\text { manufacturer (OEM) } \\
\text { - } \quad \text { Government } \\
\text { parastatals/relevant } \\
\text { ministries } \\
\text { - International aid and } \\
\text { development } \\
\text { organisations (IDOs) }\end{array}$} & 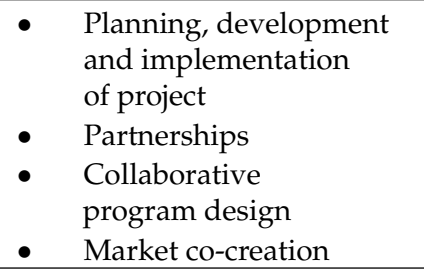 & \multirow{3}{*}{$\begin{array}{ll}\text { - } & \text { Reliable and secure local } \\
\text { electricity access } \\
\text { - } & \text { Energy efficiency as } \\
\text { a service } \\
\text { - } \quad \text { Local energy market for } \\
\text { biomass feedstock } \\
\text { - } \quad \text { Capacity building and } \\
\text { training of local } \\
\text { workforce/operators }\end{array}$} & $\begin{array}{ll}\text { - } & \text { Local } \\
\text { communities' engagements } \\
\text { - } \quad \text { Co-creation } \\
\text { (customized services) } \\
\text { - Automated on-line } \\
\text { services/platforms }\end{array}$ & \multirow[t]{3}{*}{$\begin{array}{ll}\text { - } & \text { Local communities } \\
\text { - } & \text { Non-government } \\
\text { organizations } \\
\text { (humanitarian organizations) } \\
\text { - } \quad \text { Indigenous professional } \\
\text { bodies (Manufacturers } \\
\text { Association of Nigeria (MAN) } \\
\text { - Utilities (system aggregator) }\end{array}$} \\
\hline & Key Resources & & Channels & \\
\hline & $\begin{array}{l}\text { - Skilled workforce } \\
\text { Network of practitioners, } \\
\text { field experts and relevant } \\
\text { stakeholders from the } \\
\text { academia, industry, } \\
\text { government and target } \\
\text { local communities. }\end{array}$ & & $\begin{array}{ll}\text { - } & \text { Registered management and } \\
& \text { portfolio platforms (Odyssey) } \\
\text { - } & \text { Personal networks } \\
\text { - } & \text { Government } \\
& \text { parastatals/relevant ministries } \\
\text { - } & \text { International organizations } \\
& \text { (African Development Bank } \\
\text { (AFDB), Alliance for Rural } \\
\text { Electrification (ARE)) }\end{array}$ & \\
\hline \multicolumn{2}{|c|}{ Cost Structure } & \multicolumn{3}{|l|}{ Revenue Streams } \\
\hline \multicolumn{2}{|c|}{$\begin{array}{l}\text { All the costs affiliated with the planning, deployment, operation } \\
\text { and maintenance of the RHMGs }\end{array}$} & \multicolumn{3}{|c|}{$\begin{array}{l}\text { - } \quad \text { Connection fee and sale of energy/energy services } \\
\text { - } \quad \text { Sale of bio-gasification by-products } \\
\text { - } \quad \text { Provision of ancillary grid balancing services } \\
\text { - } \quad \text { Grants, tenders and other funding opportunities like relief funds }\end{array}$} \\
\hline
\end{tabular}




\subsection{Scale up to Urban Communities and Future Work}

The bulk of the population in sub-Saharan Africa reside in rural areas [101]. However, with recent rapid urbanization rates, the issue of urban overcrowding is becoming more apparent [102]. This exacerbates the energy access problem and energy insecurity in the region. The IREP framework buttresses localized energy planning and could be scaled up to urban communities by capitalizing on the possible synergies between urban planning and energy planning strategies [103]. Adopting this strategy integration approach would deliver very optimistic results as typified by this study including energy conservation, reductions in energy demand and GHGs emission, overall energy expenditure and required optimal investments for developing community energy systems. Since urban communities present a more diversified energy consumption structure, the prevalence of smart metering avails the possibility to obtain robust and targeted energy consumption data such that incorporates other sectors or end uses not captured for rural communities. There is the opportunity to develop and diversify the urban renewable energy portfolios, improve upon urban environmental governance and peruse electricity generation from biomass wastes for effective waste management. Therefore, future work would imbibe the scale up to urban communities and consider setting up experimental systems as demonstration projects to fully implement the entire framework and ultimately set up track businesses to foster the extension of the framework to other developing countries of the world with similar peculiarities and local dichotomies. This could also be useful for designing local policies that could incentivize the uptake of uncommon RE technologies such as CHP, which have been largely unexplored whilst getting a better grasp of the intricacies and modalities of utilizing biomass gasification technology for community scale electrification. Also, future simulations could consider incorporating global control strategies to compensate for the oversimplification of this function with HOMER Pro and HOMER Grid. The prevalent urban distribution network could be incoporated in future studies to investigate its cost ramifications and impact on LCOE of decentralized RHMG system operating in grid-interactive operation. Additionally, advanced control strategies that allow for the definition of robust energy management architecture coupled with advanced predictive controls algorithms for weather and load forecast may be investigated with external software packages. Overall, this study can serve as a base for developing customized business cases as it provides valuable insights for decision makers and relevant stakeholders in the energy industry as regards deploying RHMGs and making robust investment decisions. Therefore, the implementation of these systems would involve making compromises on optimal configurations that buttress a balanced mix of financial, renewable, technical and design requirements.

\section{Conclusions}

IREP as a standardized and holistic integrated framework for improving localized energy access is crucial for locating, planning and operating decentralized renewable hybrid off-grid energy systems for localized (rural) applications in low-income countries. This study as the culmination of the IREP framework illustrated the optimal system design of hybrid mini-grids for local energy access for two communities in Nigeria. It focused on the techno-economic modeling (investment and operation optimization) of a renewable hybrid mini-grid system, evaluation of the benefits of demand side management (DSM) based on energy efficiency on the overall system economics and the conceptualization of a sustainable business model to deliver measurable socio-economic impacts in these communities. The overall method encompassed systematic steps including simulation, optimization (operation and economic optimization), sensitivity analysis, scenario analysis and business model conceptualization, which were facilitated by HOMER Pro, a techno-economic evaluation tool, and the business model canvass tool, a business model conceptualization tool. The results obtained in terms of optimal system configuration and performance are promising when compared to the typical DISCOs electricity tariff in Nigeria and the tariff of operational mini-grids in the country. Solar PV provides a means to currently reduce costs and improve environmental impact while providing electricity access in rural communities of low-income countries. Additionally, the results show that to make 
B-CHP competitive economically with PV, the economies of scales property must be incorporated and considerations made for the impact of scale cost factor. Thus policy interventions may be necessary to enable economies of scale for mass mobilzation of rural electrification projects. The results of the sensitivity analysis show that fuel prices are the most significant design variables to be taken into consideration for RHMG system implementation. The influence discount rate, PV and battery costs exert on the system economics, while significant, is contingent on the optimal system generation mix and their electricity production. Also, the DSM scenarios avail opportunities for demand curtailment, cost reductions and increased renewable uptake especially after having incorporated the costs of implementing the energy efficiency strategies. The insights gained have been inculcated in the conceptual business model to provide a clear and synthetic linkage between the value proposition and strategy for deploying RHMGs in the developing world. Ultimately, insights are useful to further the realization of the United Nations' goal of affordable and clean energy for all (SDG7) and sustainable cities and communities (SDG11). The DSM measures are also geared towards building the resilience of the local built environment whilst reducing its energy demand. The business models also support positive economic, social and environmental links geared towards synergizing rural development and energy planning endeavours. These are elements that can support realizing of SDG11 in these localities.

Author Contributions: B.U.-Conceptualization, Methodology, Data curation, Formal analysis, Investigation, Writing-Original Draft, Writing-Review \& Editing, Visualization; A.A.-Formal analysis, Investigation, Writing-Review \& Editing, Visualization; S.P.C.-Conceptualization, Methodology, Formal analysis, Supervision, Project administration, Funding acquisition. J.M.P.-Conceptualization, Methodology, Formal analysis, Resources, Writing-Review \& Editing, Supervision, Project administration; P.L.-Conceptualization, Methodology, Data curation, Formal analysis, Resources, Writing-Review \& Editing, Supervision, Project administration, Funding acquisition. All authors have read and agreed to the published version of the manuscript.

Funding: This research was funded by Eni S.p.A Italy.

Acknowledgments: This research has been facilitated by the Witte Endowment at Michighan Tecnhological University, USA.

Conflicts of Interest: The authors declare no conflict of interest.

\section{References}

1. Levin, T.; Thomas, V.M. Can developing countries leapfrog the centralized electrification paradigm? Energy Sustain. Dev. 2016, 31, 97-107. [CrossRef]

2. Liddle, B. Revisiting world energy intensity convergence for regional differences. Appl. Energy 2010, 87, 3218-3225. [CrossRef]

3. Tewdwr-Jones, M. Transforming Our World: The 2030 Agenda for Sustainable Development: Resolution Adopted by the General Assembly; DISP: New York, NY, USA, 2015.

4. Moss, T. Energy Poverty: Why We Are Still Failing Africa. Available online: https://www.weforum.org/ agenda/2019/11/energy-poverty-africa-sdg7/ (accessed on 5 January 2020).

5. Sahn, D.E.; Stifel, D.C. Urban-Rural Inequality in Living Standards in Africa. J. Afr. Econ. 2003, 12, 564-597. [CrossRef]

6. Cook, C.C.; Duncan, T.; Jitsuchon, S.; Sharma, A.; Guobao, W. Assessing the Impact of Transport and Energy on Infrastructure and Poverty Reduction; Asian Development Bank (ADB): Mandaluyong, Philippines, 2005; ISBN 971-561-580-5.

7. Herington, M.J.; Van De Fliert, E.; Smart, S.; Greig, C.; Lant, P.A. crossmark. Renew. Sustain. Energy Rev. 2017, 67, 1412-1419. [CrossRef]

8. Power for All Scaling Up Mini-Grids through Capital Infusion, Innovation, and Cross-Sector Collaboration. Available online: https://medium.com/energy-access-india/scaling-up-mini-grids-through-capital-infusioninnovation-and-cross-sector-collaboration-992c9b01ca7 (accessed on 4 December 2019).

9. Ugwoke, B.; Gershon, O.; Becchio, C.; Corgnati, S.P.; Leone, P. A review of Nigerian energy access studies: The story told so far. Renew. Sustain. Energy Rev. 2020, 120, 109646. [CrossRef]

10. Kumar, A.; Mohanty, P.; Palit, D.; Chaurey, A. Approach for standardization of off-grid electrification projects. Renew. Sustain. Energy Rev. 2009, 13, 1946-1956. [CrossRef] 
11. Ugwoke, B.; Sulemanu, S.; Corgnati, S.; Leone, P.; Pearce, J.M. The Integrated Rural Renewable and Sustainable Energy Planning Framework for Low-Income Countries. RSER 2020. in review.

12. Hiremath, R.B.; Shikha, S.; Ravindranath, N.H. Decentralized energy planning; modeling and application-A review. Renew. Sustain. Energy Rev. 2007, 11, 729-752. [CrossRef]

13. Alstone, P.; Gershenson, D.; Kammen, D.M. Decentralized energy systems for clean electricity access. Nat. Clim. Chang. 2015, 5, 305-314. [CrossRef]

14. Szabó, S.; Moner-Girona, M.; Kougias, I.; Bailis, R.; Bódis, K. Identification of advantageous electricity generation options in sub-Saharan Africa integrating existing resources. Nat. Energy 2016, 1, 1-8. [CrossRef]

15. Yadav, P.; Davies, P.J.; Sarkodie, S.A. The prospects of decentralised solar energy home systems in rural communities: User experience, determinants, and impact of free solar power on the energy poverty cycle. Energy Strateg. Rev. 2019, 26, 100424. [CrossRef]

16. Kaygusuz, K. Energy for sustainable development: A case of developing countries. Renew. Sustain. Energy Rev. 2012, 16, 1116-1126. [CrossRef]

17. African Business Magazine Nigeria Is Top FDI Destination in Africa. Available online: https://africanbusinessmagazine.com/sectors/finance/nigeria-is-top-fdi-destination-in-africa/ (accessed on 2 September 2019).

18. Sachs, G. Goldman Sachs N-11 @®Equity Portfolio. Available online: https://www.goldmansachs.com/gsam/ docs/funds_international/fund_updates/monthly_fund_updates/mfu_n11_en.pdf (accessed on 4 March 2019).

19. Okafor, F.C. Integrated Rural Development Planning in Nigeria: A Spatial Dimension. Cah. D'études Afr. 1980, 20, 83-95. [CrossRef]

20. Olatunbosun, D. Rural Development Africa-An Integrated Approach. In Proceedings of the International Workshop on Rural Development in Africa, Ibadan, Nigeria, 12-17 April 1976.

21. Mirakyan, A.; De Guio, R. Integrated energy planning in cities and territories: A review of methods and tools. Renew. Sustain. Energy Rev. 2013, 22, 289-297. [CrossRef]

22. Mirakyan, A.; Khomenko, N.; Kaikov, I.; Lelait, L. Methodological Framework for the analysis and development of a sustainable, integrated, regional energy plan-A French region case study 1. EcoMod2009 2009, 7, 1-26.

23. Ugwoke, B.; Becchio, C.; Corgnati, S.; Leone, P.; Pearce, J.M. Adapting the European Typology Approach for Building Stock Energy Assessment (TABULA) for the Developing World. JOBE 2020. in review.

24. Ugwoke, B.; Corgnati, S.P.; Leone, P.; Borchiellini, R.; Pearce, J.M. Long-range Energy Alternative Planning System Model for Renewable Energy: Community-scale Case Studies in Nigeria. J. Clean. Prod. 2020. in review.

25. Jharkhand Renewable Energy Development Agency (JREDA) Microgrid and Minigrid. Available online: https://www.jreda.com/content/95/MicrogridandMinigrid (accessed on 13 April 2020).

26. IRENA. Innovation Outlook Renewable Mini-Grids; International Renewable Energy Agency: Abu Dhabi, UAE, 2016; ISBN 978-92-95111-44-8.

27. Sinha, S.; Chandel, S.S. Review of software tools for hybrid renewable energy systems. Renew. Sustain. Energy Rev. 2014, 32, 192-205. [CrossRef]

28. Bhattacharyya, S.C. Mini-grids for the base of the pyramid market: A critical review. Energies 2018, 11, 813. [CrossRef]

29. Eras-Almeida, A.A.; Egido-Aguilera, M.A. Hybrid renewable mini-grids on non-interconnected small islands: Review of case studies. Renew. Sustain. Energy Rev. 2019, 116, 109417. [CrossRef]

30. Alliance for Rural Electrification (ARE). Hybrid Mini-Grids for Rural Electrification: Lessons Learned; Alliance for Rural Electrification: Brussel, Belgium, 2014.

31. Lyden, A.; Pepper, R.; Tuohy, P.G. A modelling tool selection process for planning of community scale energy systems including storage and demand side management. Sustain. Cities Soc. 2018, 39, 674-688. [CrossRef]

32. Gao, Y.; Meng, X.; Gao, W.; Long, E. A review of technologies and evaluation softwares for distrbuted energy source system. Procedia Soc. Behav. Sci. 2016, 216, 398-408. [CrossRef]

33. Mandelli, S.; Barbieri, J.; Mereu, R.; Colombo, E. Off-grid systems for rural electrification in developing countries: Definitions, classification and a comprehensive literature review. Renew. Sustain. Energy Rev. 2016, 58, 1621-1646. [CrossRef]

34. Trotter, P.A.; Mcmanus, M.C.; Maconachie, R. Electricity planning and implementation in sub-Saharan Africa: A systematic review. Renew. Sustain. Energy Rev. 2017, 74, 1189-1209. [CrossRef] 
35. Pearce, J.M. Photovoltaics-A path to sustainable futures. Futures 2002. [CrossRef]

36. Johnson, B.; Chang, L.; Afridi, K.; Ali, M.H.; Von Appen, J.; Chen, Y.M.; Davoudi, A.; Dhople, S.; Enslin, J.H.; Flicker, J.; et al. Guest editorial joint special section on power conversion \& control in photovoltaic power plants. IEEE Trans. Energy Convers. 2019, 34, 159-160.

37. Solar Energy Industries Association (SEIA) Solar Industry Research Data. Available online: https://www. seia.org/solar-industry-research-data (accessed on 12 April 2020).

38. Vaughan, A. Time to Shine: Solar Power Is Fastest-Growing Source of New Energy. Available online: https://www.theguardian.com/environment/2017/oct/04/solar-power-renewables-internationalenergy-agency (accessed on 12 April 2020).

39. Center for Climate and Energy Solutions (C2ES) Renewable Energy. Available online: https://www.c2es.org/ content/renewable-energy/ (accessed on 12 April 2020).

40. Apostoleris, H.; Sgouridis, S.; Stefancich, M.; Chiesa, M. Utility solar prices will continue to drop all over the world even without subsidies. Nat. Energy 2019, 4, 833-834. [CrossRef]

41. Acevedo-Arenas, C.Y.; Correcher, A.; Sánchez-Díaz, C.; Ariza, E.; Alfonso-Solar, D.; Vargas-Salgado, C.; Petit-Suárez, J.F. MPC for optimal dispatch of an AC-linked hybrid PV/wind/biomass/H2 system incorporating demand response. Energy Convers. Manag. 2019, 186, 241-257. [CrossRef]

42. Dong, L.; Liu, H.; Riffat, S. Development of small-scale and micro-scale biomass-fuelled CHP systems-A literature review. Appl. Therm. Eng. 2009, 29, 2119-2126. [CrossRef]

43. Montuori, L.; Alcázar-Ortega, M.; Álvarez-Bel, C.; Domijan, A. Integration of renewable energy in microgrids coordinated with demand response resources: Economic evaluation of a biomass gasification plant by Homer Simulator. Appl. Energy 2014, 132, 15-22. [CrossRef]

44. Islam, M.S.; Akhter, R.; Rahman, M.A. A thorough investigation on hybrid application of biomass gasifier and PV resources to meet energy needs for a northern rural off-grid region of Bangladesh: A potential solution to replicate in rural off-grid areas or not? Energy 2018, 145, 338-355. [CrossRef]

45. Yimen, N.; Hamandjoda, O.; Meva'a, L.; Ndzana, B.; Nganhou, J. Analyzing of a photovoltaic/wind/biogas/ pumped-hydro off-grid hybrid system for rural electrification in Sub-Saharan Africa-Case study of Djoundé in Northern Cameroon. Energies 2018, 11, 2644. [CrossRef]

46. Sarkar, T.; Bhattacharjee, A.; Samanta, H.; Bhattacharya, K.; Saha, H. Optimal design and implementation of solar PV-wind-biogas-VRFB storage integrated smart hybrid microgrid for ensuring zero loss of power supply probability. Energy Convers. Manag. 2019, 191, 102-118. [CrossRef]

47. Mazzola, S.; Astolfi, M.; Macchi, E. The potential role of solid biomass for rural electrification: A techno economic analysis for a hybrid microgrid in India. Appl. Energy 2016, 169, 370-383. [CrossRef]

48. Ahmad, J.; Imran, M.; Khalid, A.; Iqbal, W.; Ashraf, S.R.; Adnan, M.; Ali, S.F.; Khokhar, K.S. Techno economic analysis of a wind-photovoltaic-biomass hybrid renewable energy system for rural electrification: A case study of Kallar Kahar. Energy 2018, 148, 208-234. [CrossRef]

49. Barakat, S.; Samy, M.M.; Eteiba, M.B.; Wahba, W.I. Feasibility Study of Grid Connected PV-Biomass Integrated Energy System in Egypt. Int. J. Emerg. Electr. Power Syst. 2016, 17, 519-528. [CrossRef]

50. Eteiba, M.B.; Barakat, S.; Samy, M.M.; Wahba, W.I. Optimization of an off-grid PV/Biomass hybrid system with different battery technologies. Sustain. Cities Soc. 2018, 40, 713-727. [CrossRef]

51. Castellanos, J.G.; Walker, M.; Poggio, D.; Pourkashanian, M.; Nimmo, W. Modelling an off-grid integrated renewable energy system for rural electrification in India using photovoltaics and anaerobic digestion. Renew. Energy 2015, 74, 390-398. [CrossRef]

52. Rajbongshi, R.; Borgohain, D.; Mahapatra, S. Optimization of PV-biomass-diesel and grid base hybrid energy systems for rural electrification by using HOMER. Energy 2017, 126, 461-474. [CrossRef]

53. Sigarchian, S.G.; Paleta, R.; Malmquist, A.; Pina, A. Feasibility study of using a biogas engine as backup in a decentralized hybrid (PV/wind/battery) power generation system-Case study Kenya. Energy 2015, 90, 1830-1841. [CrossRef]

54. Nfah, E.M.; Ngundam, J.M. Feasibility of pico-hydro and photovoltaic hybrid power systems for remote villages in Cameroon. Renew. Energy 2009, 34, 1445-1450. [CrossRef]

55. Gellings, C.W.; Chamberlin, J.H. Demand-Side Management: Concepts and Methods; Fairmont Press: Lilburn, GA, USA, 1993; ISBN 088173148X.

56. Saad, M. Methods of Demand Site Management and Demand Response. Res. Rev. J. Eng. Technol. 2016, 5, 1-6. 
57. Mehra, V.; Amatya, R.; Ram, R.J. Estimating the value of demand-side management in low-cost, solar micro-grids. Energy 2018, 163, 74-87. [CrossRef]

58. Knuckles, J. Business models for mini-grid electricity in base of the pyramid markets. Energy Sustain. Dev. 2016. [CrossRef]

59. Stadler, M.; Cardoso, G.; Mashayekh, S.; Forget, T.; DeForest, N.; Agarwal, A.; Schönbein, A. Value streams in microgrids: A literature review. Appl. Energy 2016, 162, 980-989. [CrossRef]

60. International Finance Corporation (IFC) From Gap to Opportunity: Business Models for Scaling Up Energy Access; Elsevier: Washington, DC, USA, 2012.

61. Pedersen, M.B. Deconstructing the concept of renewable energy-based mini-grids for rural electrification in East Africa. Wiley Interdiscip. Rev. Energy Environ. 2016, 5, 570-587. [CrossRef]

62. Bhattacharyya, S.C. Business Issues for Mini-Grid-Based Electrification in Developing Countries. In Green Energy and Technology; Springer: Geneva, Switzerland, 2014.

63. Sustainable Energy for All Cooling as a Service: A Disruptive Business Model for Sustainable Cooling. Available online: https://www.seforall.org/news/cooling-as-a-service-a-disruptive-business-model-forsustainable-cooling (accessed on 28 March 2020).

64. Salehin, S.; Ferdaous, M.T.; Chowdhury, R.M.; Shithi, S.S.; Rofi, M.S.R.B.; Mohammed, M.A. Assessment of renewable energy systems combining techno-economic optimization with energy scenario analysis. Energy 2016. [CrossRef]

65. National Renewable Energy Laboratory (NREL). HOMER: The Micropower Optimization Model; National Renewable Energy Laboratory: Denver, CO, USA, 2004.

66. National Renewable Energy Laboratory (NREL). HOMER Pro Version 3.7 User Manual; National Renewable Energy Laboratory: Denver, CO, USA, 2016.

67. Osterwalder, A.; Pigneur, Y. Business Model Generation-Canvas; Wiley: Hoboken, NJ, USA, 2010; ISBN 978-0-470-87641-1.

68. Gabriel, C.A.; Kirkwood, J. Business models for model businesses: Lessons from renewable energy entrepreneurs in developing countries. Energy Policy 2016, 95, 336-349. [CrossRef]

69. Rural Electrification Agency (REA) 20 by 20: Mini-Grid Design Charrette to Achieve 20 Cents/kWh by 2020; Rocky Mountain Institute (RMI): Basalt, CO, USA, 2017.

70. Sobamowo, G.M.; Ojolo, S.J. Techno-Economic Analysis of Biomass Energy Utilization through Gasification Technology for Sustainable Energy Production and Economic Development in Nigeria. J. Energy 2018, 2018, 1-16. [CrossRef]

71. Diyoke, C.; Idogwu, S.; Ngwaka, U.C. An Economic Assessment of Biomass Gasification for Rural Electrification in Nigeria. Int. J. Renew. Energy Technol. Res. 2014, 3, 1-17.

72. NgPricehunter NgPricehunter-Online Shopping Nigeria. Available online: https://ngpricehunter.com/ (accessed on 23 January 2020).

73. Jumia Nigeria Jumia Nigeria: Online Shopping for Electronics, Phones \& Fashion. Available online: https://www.jumia.com.ng/ (accessed on 23 January 2020).

74. Trading Economics Nigeria Inflation Rate. Available online: https://radingeconomics.com/nigeria/inflationcpi (accessed on 21 January 2020).

75. Adesanya, A.A.; Pearce, J.M. Economic viability of captive off-grid solar photovoltaic and diesel hybrid energy systems for the Nigerian private sector. Renew. Sustain. Energy Rev. 2019, 114. [CrossRef]

76. Adesanya, A.A.; Schelly, C. Solar PV-diesel hybrid systems for the Nigerian private sector: An impact assessment. Energy Policy 2019, 132, 196-207. [CrossRef]

77. IRENA. Planning and Prospects for Renewable Energy: West Africa; IRENA: Abu Dhabi, UAE, 2018; ISBN 9789292600815.

78. IRENA. Renewable Energy Technologies: Cost Analysis Series- Biomass for Power Generation; IRENA: Abu Dhabi, UAE, 2012.

79. EnergySage Solar Panel Efficiency: What Panels Are Most Efficient? Available online: https://news. energysage.com/what-are-the-most-efficient-solar-panels-on-the-market/ (accessed on 11 February 2020).

80. Askari, I.B.; Ameri, M. Techno-economic feasibility analysis of stand-alone renewable energy systems (PV/bat, wind/bat and hybrid PV/wind/bat) in Kerman, Iran. Energy Sources Part B Econ. Plan. Policy 2012, 7, 45-60. [CrossRef] 
81. European Commission's Joint Research Centre (JRC) Photovoltaic Geographical Information System PVGIS Tool. Available online: http://re.jrc.ec.europa.eu/pvg_tools/en/tools.html\#PVP (accessed on 13 April 2020).

82. National Energy Technology Laboratory (NETL). Quality Guidelines for Energy System Studies: Capital Cost Scaling Methodology; National Energy Technology Laboratory: Pittsburg, CA, USA, 2013.

83. Situmorang, Y.A.; Zhao, Z.; Yoshida, A.; Abudula, A.; Guan, G. Small-scale biomass gasification systems for power generation (<200 kW class): A review. Renew. Sustain. Energy Rev. 2020, 117, 109486. [CrossRef]

84. Sikarwar, V.S.; Zhao, M.; Clough, P.; Yao, J.; Zhong, X.; Memon, M.Z.; Shah, N.; Anthony, E.J.; Fennell, P.S. An overview of advances in biomass gasification. Energy Environ. Sci. 2016, 9, 2939-2977. [CrossRef]

85. Dimpl, E. Small-Scale Electricity Generation from Biomass Part I-Biomass Gasification, 2nd ed.; Biomass Gasification, GIZ HERA—Poverty-oriented Basic Energy Service: Eschborn, Germany, 2011.

86. Klemm, M. Small Scale Biomass Gasification for Rural Electrification; Springer Science+Business Media: Berlin, Germany, 2019; ISBN 9781493978137.

87. Kohli, S.; Ravi, M. Biomass Gasification for Rural Electrification: Prospects and Challenges. SESI J. 2003, 13, 83-101.

88. Vakalis, S.; Sotiropoulos, A.; Moustakas, K.; Malamis, D.; Baratieri, M. Utilisation of biomass gasification by-products for onsite energy production. Waste Manag. Res. 2016, 34, 564-571. [CrossRef]

89. Enongene, K.E.; Abanda, F.H.; Otene, I.J.J.; Obi, S.I.; Okafor, C. The potential of solar photovoltaic systems for residential homes in Lagos city of Nigeria. J. Environ. Manag. 2019, 244, 247-256. [CrossRef]

90. US Census Bureau Current versus Constant (or Real) Dollars. Available online: https://www.census.gov/ topics/income-poverty/income/guidance/current-vs-constant-dollars.html (accessed on 5 April 2020).

91. Yakubu, A.; Ayandele, E.; Sherwood, J.; Olu, O.A.; Graber, S. Minigrid Investment Report: Scaling the Nigerian Market 2018; NESG: Abuja, Nigeria, 2018.

92. ESMAP. Mini grids in Nigeria: A Case Study of a Promising Market; World Bank Group: Washington, DC, USA, 2017.

93. P.M. News New Electricity Tariffs for Nigerian Consumers from April (Full Tariff Lists). Available online: https://www.pmnewsnigeria.com/2020/01/05/new-electricity-tariffs-for-nigerian-consumers-fromapril-full-tariff-lists/ (accessed on 7 April 2020).

94. Energy Sector Management Assistance Program. Mini-Grids in Nigeria; World Bank: Washington, DC, USA, 2017.

95. Kenton, W. Net Present Value (NPV). Available online: https://www.investopedia.com/terms/n/npv.asp (accessed on 14 April 2020).

96. Modanese, C.; Laine, H.S.; Pasanen, T.P.; Savin, H.; Pearce, J.M. Economic advantages of dry-etched black silicon in passivated emitter rear cell (PERC) photovoltaic manufacturing. Energies 2018, 11, 2337. [CrossRef]

97. Mauleón, I. Photovoltaic learning rate estimation: Issues and implications. Renew. Sustain. Energy Rev. 2016, 65, 507-527. [CrossRef]

98. Mauleón, I.; Hamoudi, H. Photovoltaic and wind cost decrease estimation: Implications for investment analysis. Energy 2017, 137, 1054-1065. [CrossRef]

99. Görig, M.; Breyer, C. Energy learning curves of PV systems. Environ. Prog. Sustain. Energy 2016, 35, 914-923. [CrossRef]

100. Wittbrodt, B.; Pearce, J.M. 3-D printing solar photovoltaic racking in developing world. Energy Sustain. Dev. 2017, 36, 1-5. [CrossRef]

101. World Bank Group Rural Population (\% of Total Population)—Sub-Saharan Africa Data. Available online: https://data.worldbank.org/indicator/SP.RUR.TOTL.ZS?locations=ZG (accessed on 31 October 2019).

102. Tao, L.W. The drawbacks of housing overcrowding characteristic to rural migrants' life in Beijing. HBRC J. 2017, 13, 315-320. [CrossRef]

103. de Collaço, F.M.A.; Simoes, S.G.; Dias, L.P.; Duic, N.; Seixas, J.; Bermann, C. The dawn of urban energy planning-Synergies between energy and urban planning for São Paulo (Brazil) megacity. J. Clean. Prod. 2019, 215, 458-479. [CrossRef]

(C) 2020 by the authors. Licensee MDPI, Basel, Switzerland. This article is an open access article distributed under the terms and conditions of the Creative Commons Attribution (CC BY) license (http://creativecommons.org/licenses/by/4.0/). 